\title{
Wall paintings through the ages: the roman period-Republic and early Empire
}

\author{
Monica Salvadori ${ }^{1}$ (D) $\cdot$ Clelia Sbrolli $^{1}$
}

Received: 1 February 2021 / Accepted: 30 June 2021 / Published online: 13 October 2021

(C) The Author(s) 2021

\begin{abstract}
This paper aims at presenting an overview of Roman wall painting production between late Republic and the early Empire. It will focus on the technique and style of in situ wall paintings from the Vesuvian area (Italy). Frescoes are indeed an integral part of architecture and reflect the patrons' ambitions and social level as well as the craftsmen's technical know-how. Since this is a handicraft product, the quality of materials, the craftsmen's skills and the technique are fundamental to understand the fresco's value and the message that the patron wished to communicate through the use of elaborate schemes, expensive colours or certain mythological themes.
\end{abstract}

Keywords Roman wall painting $\cdot$ Painting technique $\cdot$ Technology $\cdot$ Craftsmanship $\cdot$ Pompeian styles

\section{Premise}

This Topical Collection (TC) covers several topics in the field of study, in which ancient architecture, art history, archaeology and material analyses intersect. The chosen perspective is that of a multidisciplinary scenario, capable of combining, integrating and solving the research issues raised by the study of mortars, plasters and pigments (Gliozzo et al. 2021).

The first group of contributions explains how mortars have been made and used through the ages (Arizzi and Cultrone 2021, Ergenç et al. 2021, Lancaster 2021, Vitti 2021). An insight into their production, transport and on-site organisation is further provided by DeLaine (2021). Furthermore, several issues concerning the degradation and conservation of mortars and plasters are addressed from practical and technical standpoints ( $\mathrm{La}$ Russa and Ruffolo 2021, Caroselli et al. 2021).

The second group of contributions is focused on pigments, starting from a philological essay on terminology (Becker in

This article is part of the Topical Collection on Mortars, plasters and pigments: Research questions and answers

Monica Salvadori

monica.salvadori@unipd.it

Clelia Sbrolli

clelia.sbrolli@gmail.com

1 University of Padua, Padua, Italy press). Three archaeological reviews on prehistoric (Domingo Sanz and Chieli 2021), Roman (This paper) and Medieval (Murat 2021) wall paintings clarify the archaeological and historical/cultural framework. A series of archaeometric reviews illustrate the state of the art of the studies carried out on Fe-based red, yellow and brown ochres (Mastrotheodoros et al. 2021); Cubased greens and blues (Švarcová et al. 2021); As-based yellows and reds (Gliozzo and Burgio 2021); Pb-based whites, reds, yellows and oranges (Gliozzo and Ionescu 2021); Hg-based red and white (Gliozzo 2021); and organic pigments (Aceto 2021). An overview of the use of inks, pigments and dyes in manuscripts, their scientific examination and analysis protocol (Burgio 2021) and an overview of glass-based pigments (Cavallo and Riccardi 2021) are also presented. Furthermore, two papers on cosmetic (Pérez Arantegui 2021) and bioactive (antibacterial) pigments (Knapp et al. 2021) provide insights into the variety and different uses of these materials.

\section{Introduction}

The history of Roman painting is mainly a history of wall painting. Instead, there is almost no or scarce evidence of portable paintings on wooden panels (the Fayum mummy portraits and the pinakes - boards - from Pitsà represent precious exceptions), or other types of support like marble, of which the monochromata of Herculaneum are a famous/ paradigmatic example (Sampaolo 2009; Lenzi 2016). 
Frescoes have been found in diverse conditions, either they had remained in situ, i.e. in the original context which they belonged to, or fallen in fragments following the wall's collapse or reused as debris in different contexts - even in landfills (Carrive 2017).

As regards in situ frescoes, the Vesuvian area (Southern Italy) offers exemplary evidence; it has attracted great interest from scholars since the discovery of Pompeii and Herculaneum. It has been repeatedly emphasised indeed that the frescoes preserved in situ - that is, as an integral part of the building - qualify the function of the rooms, contribute to defining the paths of use of the building itself, and may also reflect the patrons' ambitions and social level (WallaceHadrill 1994). Recently, it has also been observed how much the typology and lexicon of the so-called Pompeian styles have influenced studies in Roman painting (Bragantini 2019). Nonetheless, it should be noted that the corpus of wall paintings found in different areas of the Roman Empire has increased in recent decades; such evidence is most often fragmentary and lacunose, difficult to fit into an overall scenario though (Dubois and Niffeler 2018).

The need to improve documentation highlights the importance of collecting fragmentary paintings during archaeological excavation: great attention must be paid to recording the connections between the fragments, which must be numbered, documented through photographs and by means of surveys, in order to facilitate subsequent remounting. The phases of recovery and reassembly are extremely important because they allow to enrich a documentation that otherwise would remain only circumstantial (Barbet 2016; Groetembril 2016).

In order to reconstruct large portions of the painting from its fragments, a careful analysis of the "key elements" is essential: on the surface, it might be possible to detect the direction of the brushstrokes, distinguish the streaks left by the brush or identify the preparatory marks (see paragraph Sketches, outline incisions and corda battuta (chalk-line). On the fragments' back, instead, it might be possible to see the traces of the wall masonry, or the expedients used to facilitate the adhesion of the plaster to the roofs. In the latter case, in fact, the negative grooves of the canes that formed the structure to which the ceiling frescoes adhered might be of great help. To recognise elaborate or partially preserved decorative motifs, the researcher uses his/her experience and knowledge of ancient paintings, as if he/she "mentally browses" through a corpus of images (Barbet 2016; Groetembril 2016).

The fragments are then reassembled by placing them in sand boxes so that they are stable on a uniform level. Once the surfaces have been recomposed, they are documented graphically and photographically. When possible, a digital or 3D graphic reconstruction of the painting and its architectural context is also elaborated that will allow a better reading of both the painting and the context and facilitate the display
(Barbet 2016; Groetembril 2016). Archaeometric analyses might contribute to studying wall paintings as well; through such techniques, we might acquire better knowledge of pigments, mortars and plasters, both in terms of technological, economic and commercial implications (Aliatis et al. 2010; Béarat et al. 1997; Becker in press).

Thereby, putting together all the aspects of wall painting production allows to reconstruct the characteristics of the architectural context, the technical know-how of the craftsmen and the economic and social value of the paintings.

Since this is an artisanal product (Bragantini 2004), the quality of the materials, the craftsmen's skills and the technique are fundamental to understand the value of the wall painting and the message that the patron wished to communicate through the use of elaborate schemes, expensive colours or certain mythological themes.

Wall paintings are indeed an instrument of personal propaganda of the dominus within his own home. Such propagandistic function of wall paintings thus leads to the development of the "styles" and the craftsmen's technical skills, and the dissemination of models considered to be meaningful (Bragantini and Sampaolo 2009; Flohr 2019).

For the sake of synthesis, within the limited space of this paper, it is not possible to go deep into the analysis of the various perspectives related to Roman wall painting. For this reason, this paper will rather provide a general overview of the topic. The first part offers a brief insight into the ancient written sources concerning wall painting, while the second and third sections focus respectively on the technique of execution of the support (the laying of the different coats of plaster, their consolidation, the use of guidelines and preparatory sketches for the basic outline of the decorative system), and on the painting techniques and the process of finishing the paint film.

The central part of the paper is dedicated to the concept of "style" as far as it has been applied to the decorative systems of Roman wall painting, offering a diachronic overview of this production between late Republic and early Empire. It provides examples of the first models of Greek derivation popular in the second-early first century BC (first style), the articulated systems of perspective architectures that dominated the first century BC (second style), the fictitious ornamental systems typical of the Augustan age (third style), in which the figurative paintings stand out against monochrome backgrounds, and the eclectic creations in vogue immediately after the middle of the first century AD (fourth style), when the return of unreal architectural perspectives is combined with flat backgrounds hosting "flying" figures and small paintings in the centre.

The last part of the article explores what were the figurative repertoire - a key to understand the qualitative level of the decorative systems and the ambitions of the patrons - and the most fashionable models in vogue from the late Republic 
to the early Empire, namely megalographies, mythological paintings, garden representations and landscapes.

\section{Ancient sources}

Sed nulla gloria artificum est nisi qui tabulas pinxere. (Plin., Nat. XXXV, 118 à $X X X V, 37,118$ )

Pliny the Elder's passage explicitly states that only paintings on wooden panels were considered the work of a true artist; on the contrary, wall paintings, which were very popular in the decoration of any house at Pliny's time (early Roman Empire), were only expressions of the house owner's luxury and wealth.

These reflections (of Pliny) are to be taken into account when analysing ancient Roman painting.

Book XXXV of the Naturalis Historia mentions several names of illustrious Greek painters, including Panaenus, the brother of Phidias, who painted the battle of the Athenians against the Persians, and Polygnotus from Thasos, who painted, among others, the Stoà poikile in Athens, Zeuxis, Parrhasius and Apelles, to name but the most distinguished masters. Many of these artists' works were brought to Rome as spoils of war during the Roman conquest of Greece; some of them gave birth to Rome's famous public pinacothecas (pictures-galleries), such as the one in the Porticus of Octavia. Public galleries, in their turn, soon inspired to the citizens a desire of cultural appropriation and, consequently, the development of a veritable art market.

Unfortunately, most paintings made on wooden panels got lost over the centuries. References to some of these masterpieces can be found in their copies and imitations in wall paintings or mosaics floors. Among all the examples, it is sufficient to mention the famous mosaic in the House of the Faun in Pompeii representing the battle of Alexander the Great against the Persians, likely a reproduction of a fourth century BC work by the painter Philoxenus of Eretria.

Referring to past sources, Pliny also reports that between the end of the fifth and the fourth century BC, Greek painters fully mastered the rules of perspective and were completely aware of the potential offered by the chiaroscuro. In particular, the painter Apollodorus, known as the skiagraphos (i.e. the "painter of shadows"), who lived at the end of the fifth century $\mathrm{BC}$ extended the use of the chiaroscuro from the rendering of architecture (a field already experimented by Agatharchus of Samos, the painter of Aeschylus' stage settings (Rouveret 1989) to the representation of the human body.

Archaeological discoveries made over the last 50 years, especially those relating to the cist graves and chamber tombs of Macedonia, have provided evidence of the high level reached by Greek painting during the transitional phase from the Classical to the Hellenistic age in terms of space rendering, human body modelling and use of foreshortening images. A clear example are the extraordinary paintings of Vergina, such as the well-known frieze with a hunting scene in the so-called Tomb of Philip or the scene of Persephone's abduction in the homonymous tomb (Brecoulaki 2006).

Pliny's pages also reveal the names of some painters who worked in Rome between the Republic and the First Empire. These names suggest that in the middle Republic painting was sometimes practised by members of the aristocracy. For example, in 304 BC, Fabius Pictor, a descendent of the (noble) Fabii family, was commissioned to decorate the Temple of Salus: the painter, who is also mentioned by other literary authors like Cicero (Tusculanae disputationes, I, 2.4) and Dionysius of Halicarnassus (Ant. Rom. XVI, 3.6), should have painted historical episodes from the second Samnite war that became famous for the quality of the drawing and the use of chromatic mixtures. Much later, in the second century $\mathrm{BC}$, the poet Pacuvius realised the paintings in the Temple of Hercules in the Forum Boarium, dedicated by Scipio Aemilianus: it is very likely that he painted frescoes representing the battle of Pidna (168 BC), where the Aemilianus fought and won against Perseus of Macedon.

By mentioning these artists, including also the knight Turpilius from Venetia, whose notable artworks can be seen in Verona, Pliny emphasises that painting was seldom practised by high status citizens. The aforementioned aristocrat artists are to be considered exceptions to the rules indeed, as while drawing was part of Greek aristocrat education, in the Roman world, it was not considered worthy of the same consideration and only men of humble rank usually worked as painters.

During the second and first centuries BC, with the Roman nobilitas' growing passion for collecting Greek artworks, many Greek painters came to Rome. The Athenian painter Metrodoros, for instance, who was also a notable philosopher, was called upon by L. Aemilius Paullus to realise the paintings to be paraded during his famous triumph of $167 \mathrm{BC}$. The painter Alexander Demetrios, who lived in Rome in the middle of the second century BC, was called the topographus, a title variously interpreted either as painter of topia/places, referring to the genre of landscape painting, or as painter of cartographic maps (La Rocca 2004).

Book XXXV of Pliny's Naturalis Historia is thus an indispensable source not only for understanding the development of Greek painting, but also for interpreting the social implications of Roman wall painting.

Book VII of the De Architectura by Vitruvius, an architect active in the second half of the first century $\mathrm{BC}$, is another fundamental reference for two reasons: first, because of the valuable information it provides regarding the technique of plastering and preparation of the pictorial surface and, second, because it synthesises the evolution of the wall decoration systems, thereby providing an unavoidable basis for interpreting the "styles" of Roman painting. 
At the beginning of chapter 5 (Vitr. arch. VII 5,1), Vitruvius describes the wall decoration fashion trends appreciated by the "ancients": "Namque pictura imago fit eius quod est seu potest esse, uti hominis aedificii navis reliquarumque rerum, e quibus finitis certisque corporibus figurata similitudine sumuntur exempla. Ex eo antiqui qui initia ex politionibus instituerunt imitati sunt primum crustarum marmorearum varietates et conlocationes, deinde coronarum et siliculorum cuneorum inter se varias distributiones" .

Later on, the Roman architect lists more in detail the figurative elements, which in some cases are related to the characteristics of the settings (Vitr. arch. VII 5, 2): "Postea ingressi sunt ut etiam aedificiorum figuras, columnarum et fastigiorum eminentes proiecturas imitarentur, patentibus autem locis uti exhedris propter amplitudines parietum scaenarum frontes tragico more aut comico seu satyrico designarent, ambulationibus vero propter spatia longitudinis varietatibus topiorum ornarent $\mathrm{ab}$ certis locorum proprietatibus imagines exprimentes. Pinguntur enim portus promuntoria litora flumina fontes euripi fana luci montes pecora pastores, nonnulli locis item signorum megalographiam habentes deorum simulacra seu fabularum dispositas explicationes, non minus Troianas pugnas seu Ulixis errationes per topia, ceteraque quae sunt eorum similibus rationibus ab rerum natura procreata",

Lastly, Vitruvius strongly criticises the fashion trend of his own time, i.e. that emerging in the last decades of the first century BC (Vitr. arch. VII 5, 3-4).

"Sed haec quae ex veris rebus exempla sumebantur, nunc iniquis moribus inprobantur. Nam pinguntur tectoriis monstra potius quam ex rebus finitis imagines certae. Pro columnis enim struuntur calami, pro fastigiis appagineculi cum crispis foliis et volutis, item candelabra aedicularum sustinentia figuras, supra fastigia earum surgentes ex radicibus cum volutis teneri flores habentes in se sine ratione sedentia sigilla, non minus coliculi dimidiata habentes sigilla alia humanis alia bestiarum capitibus. Haec autem nec sunt nec fieri possunt nec

\footnotetext{
1 "For by painting an image is made of what is, or of what may be; for example, men, buildings, ships, and other objects; of these definite and circumscribed bodies, imitations are taken and fashioned in their likeness. Hence the ancients who first used polished stucco, began by imitating the variety and arrangement of marble inlay; then the varied distribution of festoons, ferns, coloured strips"-F. Granger, Trans.

2 "Then they proceeded d to imitate the contours of buildings, the outstanding projections of columns and gables; in open spaces, like exedrae, they designed scenery on a large scale in tragic, comic, or satyric style; in covered promenades, because of the length of the wall, they used for ornament the varieties of landscape gardening, finding subjects in the characteristics of particular places; for they paint harbours, headlands, shores, rivers, springs, straits, temples, groves, hills, cattle, shepherds. In places, some have also the anatomy of statues, the images of the gods, or the representations of legends; further, the battles of Troy and the wanderings of Ulysses over the countryside with other subjects taken in like manner from Nature"-F. Granger, Trans.
}

fuerunt. Quemadmodum enim potest calamus vere sustinere tectum aut candelabrum ornamenta fastigii seu coliculus tam tenuis et mollis sustinere sedens sigillum aut de radicibus et coliculis ex parte flores dimidiataque sigilla procreari?"3

\section{Preparation techniques}

How painters' workshops were composed and organised is much debated within the scientific community; indubitably, they included artisans from various social backgrounds (slaves, liberti, of freed status - Esposito 2009; Plisecka 2011) and comprised apprentices and craftsmen with specific tasks. Scholars have formulated two main hypotheses. Some scholars have assumed that painters' workshops were composed of independent workers who were called upon to work from time to time, depending on the building. Other scholars (instead) have supposed the existence of fixed teams of painters (Allison 1995; Esposito 2009; Moormann 1995a, pp. 109; 174-175). Moreover, it cannot be excluded that, in the case of a particularly demanding commission, a specific team could be gathered together according to single workers' specific skills and expertise (Settis 2006; Esposito 2009). Nevertheless, the complexity of some decorations, the speed and manifold tasks required to execute a fresco suggest that permanent workshops of painters used to close and steady cooperation existed (Esposito 2007, 2009, 2011, 2016a, 2016b).

The rhythm of work was articulated by the plaster's drying time and required numerous craftsmen to work simultaneously. Each one therefore had specific roles and tasks that were based on his experience and skills and worked according to a well-established practice. A unique example of labour organisation is the so-called Stele of Sens (the Gallic Agedincum), dating to the second to third century AD. This is a funerary monument representing a work scene: on the left, seated on a

\footnotetext{
3 "But these which were imitations based upon reality are now disdained by the improper taste of the present. On the stucco are monsters rather than definite representations taken from definite things. Instead of columns there rise up stalks; instead of gables, striped panels with curled leaves and volutes. Candelabra uphold pictured shrines and above the summits of these, clusters of thin stalks rise from their roots in tendrils with little figures seated upon them at random. Again, slender stalks with heads of men and of animals attached to half the body.

Such things neither are, nor can be, nor have been. On these lines the new fashions compel bad judges to condemn good craftsmanship for dullness. For how can a reed actually sustain a roof, or a candelabrum the ornaments of a gable ? or a soft and slender stalk, a seated statue? or how can flowers and halfstatues rise alternately from roots and stalks?"-F. Granger, Trans.
} 
ladder, the redemptor (the master builder) is intent on consulting a scroll, which perhaps reproduces the general sketch of the decoration to be transposed to the wall; below, on the right, near the scaffolding, a worker wearing a short tunic, probably an apprentice, is mixing lime, sand and water to prepare the plaster. Above him, on the scaffolding, the tector (plasterer) is applying the mixture to the wall using a float, while next to him another craftsman is drawing the basic lines of the decoration by brush on the upper layer of plaster (infra intonachino) (Adam 1988).

The Stele, like a freeze-frame, offers a snapshot of the different activities underlying Roman wall painting and shows the craftsmen and operations that are indispensable to execute a good "a fresco" decoration (Fig.1).
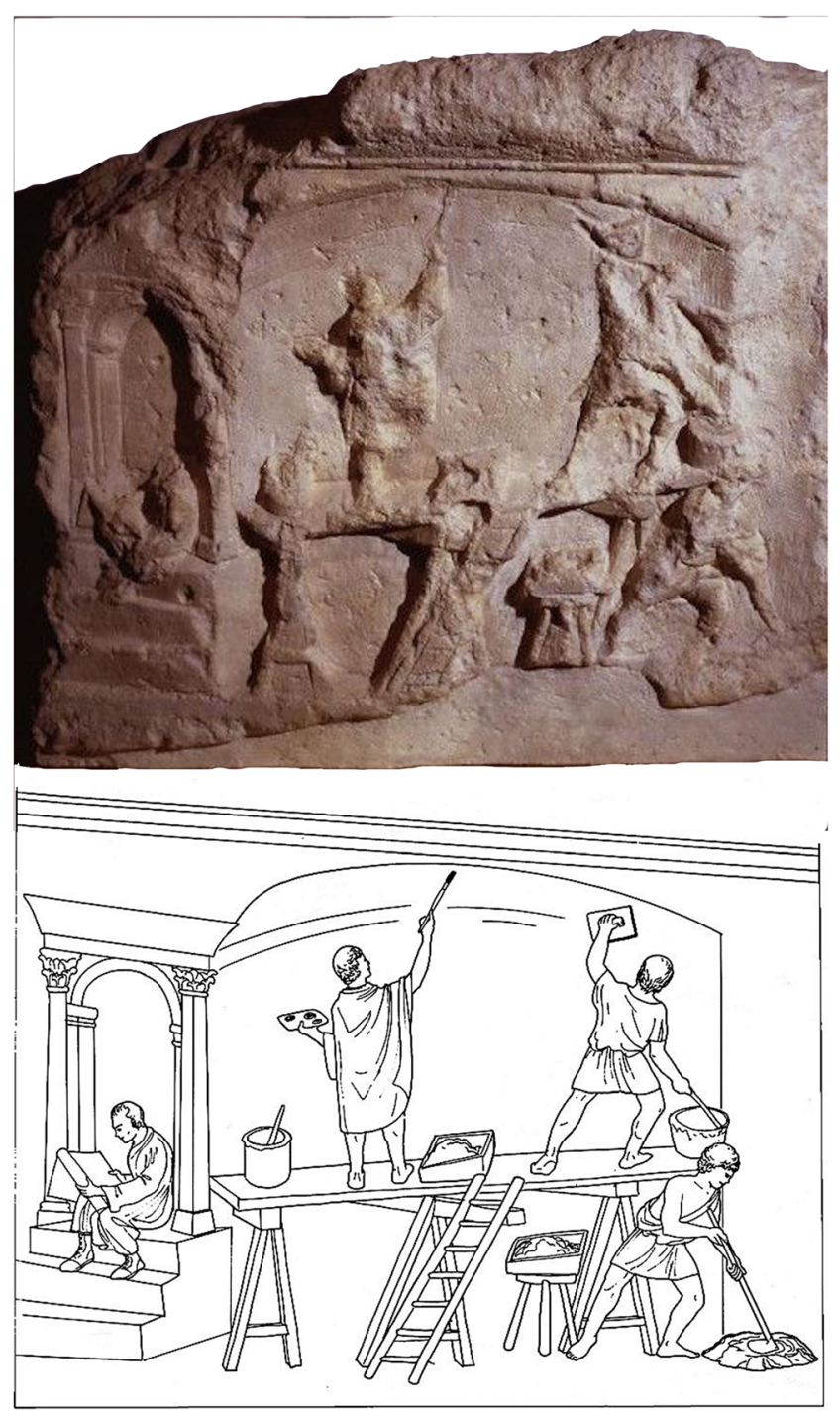

Fig. 1 Sens stele and its graphic restitution (Donati 1998, p 105)

\section{Characteristics of tectorium and preparatory layers of mortar}

Archaeological evidence confirms what literary and iconographic sources report about execution phases and craftsmens' work so that it is possible to attribute each operation to its executor. Plaster, or tectorium, was applied to the walls in a series of successive and progressively thinner layers by craftsmen called tectores, who were assisted by slaves or young apprentices mixing the lime. Unlike Vitruvius and Pliny's descriptions (recommending seven and five preparatory layers respectively-Vitr. arch. VII 3, 7; Plin. nat. XXXVI, 176 à XXXVI, 50, 176), layers of tectorium documented in archaeological sites generally do not have more than three or four. They represent an exception of some contexts of imperial property though, whose decorations are particularly precious both in terms of technical execution and decorative repertoire (like the tablinum of the House of Livia on the Palatine, the Villa della Farnesina in Rome and the Villa of Livia at Prima Porta, having six layers of plaster, or the Aula Isiaca on the Palatine, presenting four-Jacopi 2007; Vlad Borrelli 2015).

The first layer of plaster, called trullissatio, was an inner plaster layer directly applied onto the surface of the wall in order to make it more regular. The arriccio (harenatus) was then laid on; it was rather coarse as well and consisted of lime mixed with sand or pozzolana and medium-sized inclusions such admixture, gravel and/or fired clay. Then, the outer plaster layer (intonaco) was laid on; it had finer grained aggregates consisting of marble dust or, more frequently, sparry calcite (Daniele and Gratziu 1996). The last render layer (intonachino) was then applied and painted; usually, it has the same composition of the lower layer, but its grain size is even finer. Sometimes, red pigment was added to the plaster mixture in order to optimise the surface that would be painted and calibrate the intensity of the colours (supplementary figure - section of plaster fragment with pigmented intonachino).

Lastly, the plaster was smoothed and polished with a flat tool similar to a spatula (liaculum), and the pigments were applied (Barbet and Allag 1972; Barbet 1998; Barbet 2000; Bianchi 2009; Esposito 2009).

When a fresco decoration lacks one of these fundamental layers (arriccio, intonaco or intonachino) or has not been executed following to process described above, the result is a fairly cursory work which does not last (Vitr. arch. VII 3, 8).

\section{Plaster anchoring systems}

In order to facilitate the adhesion between the plaster and the surface of the wall while also avoiding detachments between the layers of the tectorium, Roman painters used various anchoring systems (Barbet and Allag 1972; Abad Casal 1982). The imprints left by such anchors on the back of the fragments 
make it possible to recognise the technique and features of the wall surface.

A frequent type of anchoring system consisted of making incisions or grooves in the damp plaster, either by hand (chevrons/keying patterns) or using a trowel to create a geometric or herringbone pattern, as shown by the Gallo-Roman House of the Messii at Vaison-la-Romaine (Fig. 2a-Ling 1991).

Another diffuse adhesion system was spatulating, that is, laying on unsmoothed layers of plaster to create a rough and irregular surface and inserting ceramic fragments in the first layer of plaster worked well too. Both these methods, used in combination, are attested in room (29) of the House of M. Epidius Sabinus (IX, 1, 22-29) in Pompeii (Fig. 2b). The addition of fired clay pieces produced an irregular surface suitable for anchoring subsequent plaster layers indeed. The most widespread technique though, which was used especially for re-decoration works, is chiselling. It consists of pecking the surface of a fresco to be obliterated in order to make it rough and thus proper for a new fresco painting. This system permitted to quickly renew the decoration of one or more rooms creating a good quality tectorium without removing the previous layers of plaster. A clear example of this practice is represented by the successive decorative phases visible in rooms (8) and (9) of the Caseggiato degli Aurighi in Ostia (III, $\mathrm{X}$ ), where during the enlargement of one of the two contiguous rooms, the old frescoes ware pecked and new ones painted over them (Fig. 2c-Falzone 2007). Other times, probably due to lack of money or time, the surface is simply repainted by applying a layer of limewater over the old fresco, without pecking. However, this technique resulted in poor, low-quality decoration.

With regard to the decoration of ceilings, the incannucciata (reed leaves wattle) allowed to create a light but resistant anchor (Vitr. arch. VII 3, 2). It was made using bundles of reeds or other plants tied together with ropes and proved useful for covering both flat ceilings and vaults.

The incannucciata left its imprints on the back of the plaster (arriccio), which appear like deep parallel grooves crossed by perpendicular incisions corresponding to the bindings. The analysis of these imprints makes it possible to estimate the diameter of the bundles of reeds and how they warped (Fig. 2d).

\section{Sketches, outline incisions and corda battuta (chalk- line)}

Once the tectorium had been applied, the pictores (painters) laid out the design and decorative element in the wet plaster.
Fig. 2 a Wall plaster with herringbone pattern, House of the Messii, Vaison-la-Romaine (France) (Ling 1991, p 198). b Spatulating and insertion of ceramic fragments, Casa di M. Epidius Sabinus (IX, 1, 2229), Pompeii (photo by author). c Pecked surface, Caseggiato degli Aurighi, Ostia Antica (photo S. Falzone). d Imprints of incannucciata, Narbonne (Capus and Dardenay 2014, p 111)

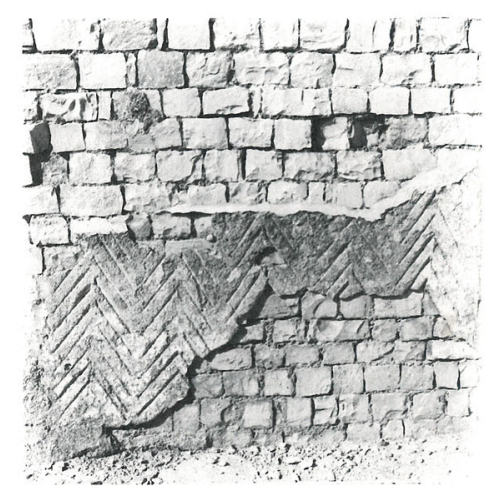

a

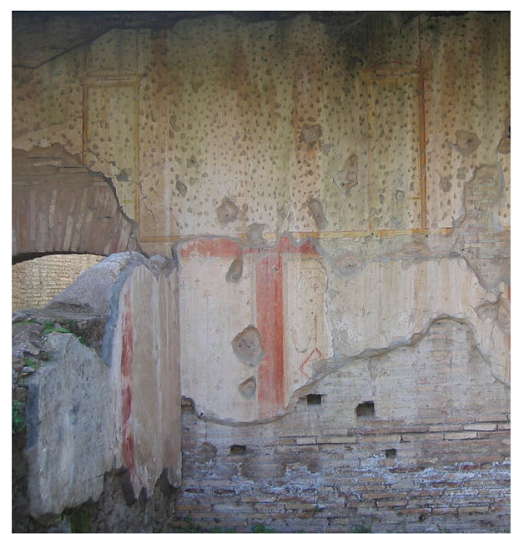

C

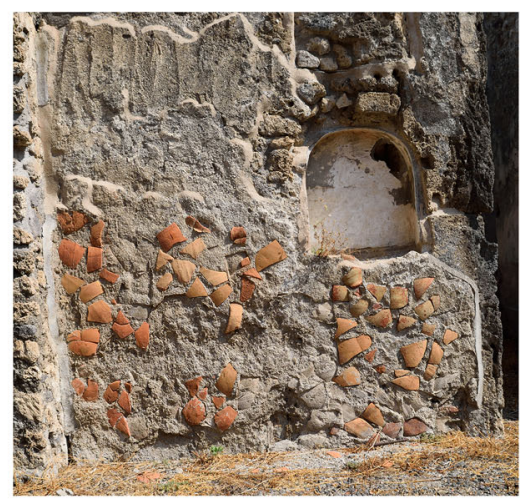

b

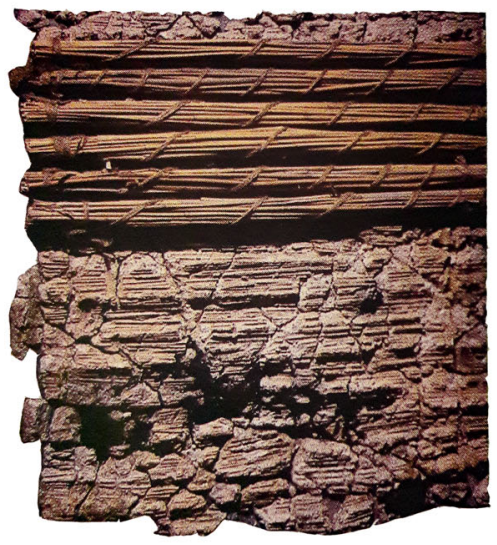

d 
To draft the fundamental lines of the decoration, painters often used a line-snapping technique (chalk-line): they fixed a string (often soaked in ochre) to the wall with two nails and stretched and bounced it on the fresh plaster in order to imprint vertical or horizontal guidelines (Fig. 3a). This technique was also useful to trace the lines of geometric decorative systems or repetitive patterns (wallpaper/Tapetenmuster), which were very common in ceiling decoration (Ling 1991).

The most complex figurative elements instead were executed tracing over a preliminary sketch drawn on the intonachino just before applying the paint. Such drawing, similar to the Renaissance's sinopia, was traced with a brush, usually in ochre or soot, to outline the main elements of complex figurative compositions, single figures or other decorative motifs. A remarkable example of sinopia is the famous incomplete painting in room (12) of the House of Painters at Work (IX 12, 9) in Pompeii. In the centre of zone 2, on the northern wall, it is possible to distinguish the preparatory drawings on the white background of the plaster; made with a brush soaked in an ochre pigment, they were used to sketch the people in a crowd (Esposito 2016a). The lower portions of at least two male figures can be recognised; the both of them are wearing short tunics and are advancing from right to left towards a seated female figure. The woman is draped in a long robe; the sketches of its soft folds are detectable as well (Fig. 3b).
Instead, the painters who executed the huge figures of athletes and architectural features on the walls of the porticus (f) of the Palestra degli Iuvenes (VIII 2, 23) were guided by preliminary soot sketches. Due to the deterioration of colour and the detachment of the paint film, it is possible to recognise the preliminary drawings, originally covered by successive layers of colour.

Preparatory sketches drawn directly on the plaster could also be used as a test or model for the decorative elements to be executed.

Particularly striking examples are the Corinthian capital sketched in yellow and red ochre along the south wall of the cubicle $(\mathrm{k})$ of the House of Ceres in Pompeii (I 9, 13-14) and the peacock feather traced in soot black on the northern wall of the fauces of the House of the Wooden Partition in Herculaneum; both these preliminary drawings were revealed due to the deterioration and fall of the paint film, which laid bare the intonachino (PPM II).

In the first case, the capital being larger and out of alignment as compared to the other capitals painted in the room, it might be argued that it was a test sketch the pictor made when setting up the decorative partitions in order to define their shape and size (Fig. 3c). In the second case, instead, the feather seems to have been a
Fig. 3 a Imprint of chalk-line, Sarno Baths (VIII 2, 17), Pompeii (photo by author). b Sinopia, Casa dei Pittori al Lavoro (IX 12, 9), Pompeii (photo A. Malgieri). c Preparatory sketches, Casa di Cerere (I 9, 13-14), Pompeii (PPM II, p 223)

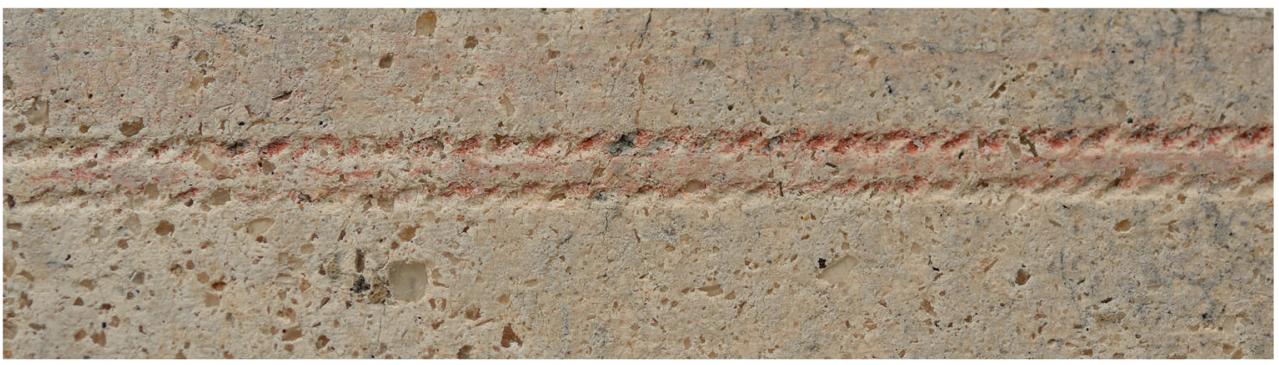

a

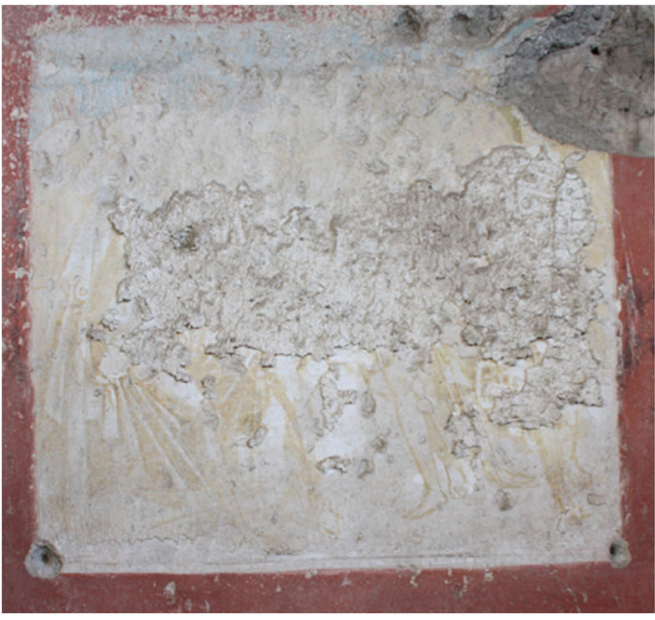

b

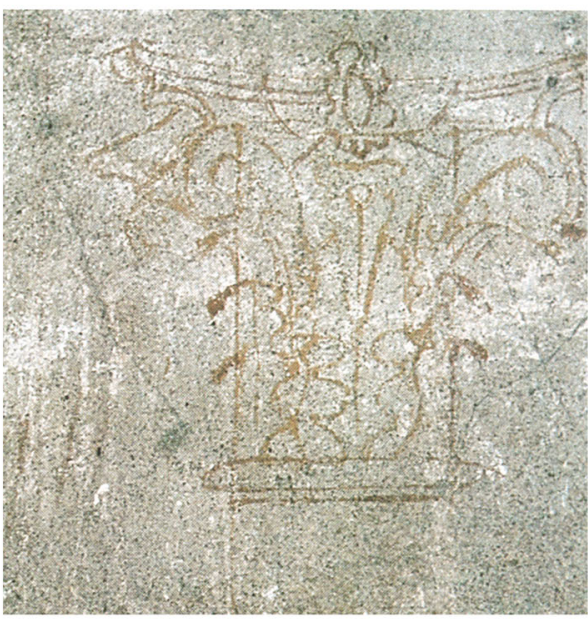

C 
reference model for the correct execution of the decorative motif that would be realised in the frieze.

Along with sinopias, preparatory incisions were common as well. These preliminary sketches were engraved on the wet plaster using a sharp tool and could be executed either freehand or using rulers and squares (direct incisions), depending on the decorative element to be reproduced (Fig. 4a), or by tracing over a model (indirect incisions). For designing circular or semi-circular motifs, painters used compasses, whose mark is easily recognisable from the perfect circumference and the hole in the centre of it (Fig. 4b). Indirect incisions, on the other hand, are characterised by clear, rounded contours and regular, continuous mark; they are particularly useful for outlining the shape of a figure or defining figurative details (Malgieri 2013; Salvadori et al. 2015) (Fig. 4c).

\section{Painting techniques}

\section{Affresco, mezzo-fresco, a secco, surface treatment and finishing}

Drawing on Vitruvius and Pliny, Roman wall painting has traditionally been thought to be entirely "a fresco" (Vitr. arch. VII; Plin. nat. XXXV). However, archaeological evidence shows ancient pictores that were well versed in the timing and practices of fresco painting using different techniques for the various phases of the wall decoration (Vitr. arch. VII 3, 8: "Itaque tectoria, quae recte sunt facta, neque vetustatibus fiunt horrida neque, cum extergentur, remittunt colores, nisi si parum diligenter et in arido fuerint inducti. cum ergo ita in parietibus tectoria facta fuerint, uti supra scriptum est, et
Fig. 4 a Incisions, Palestra degli Iuvenes (VIII 2, 23), Pompeii (photo C. Boschetti). b Mark of compasses, Casa I E/F,

Hellenistic-Roman quarter, Agrigento (Lepore, Caminneci 2019). c Preliminary sketch of a griffon, Casa della Fontana Piccola (VII 8, 23), Pompeii (Ling 1991, p 203)

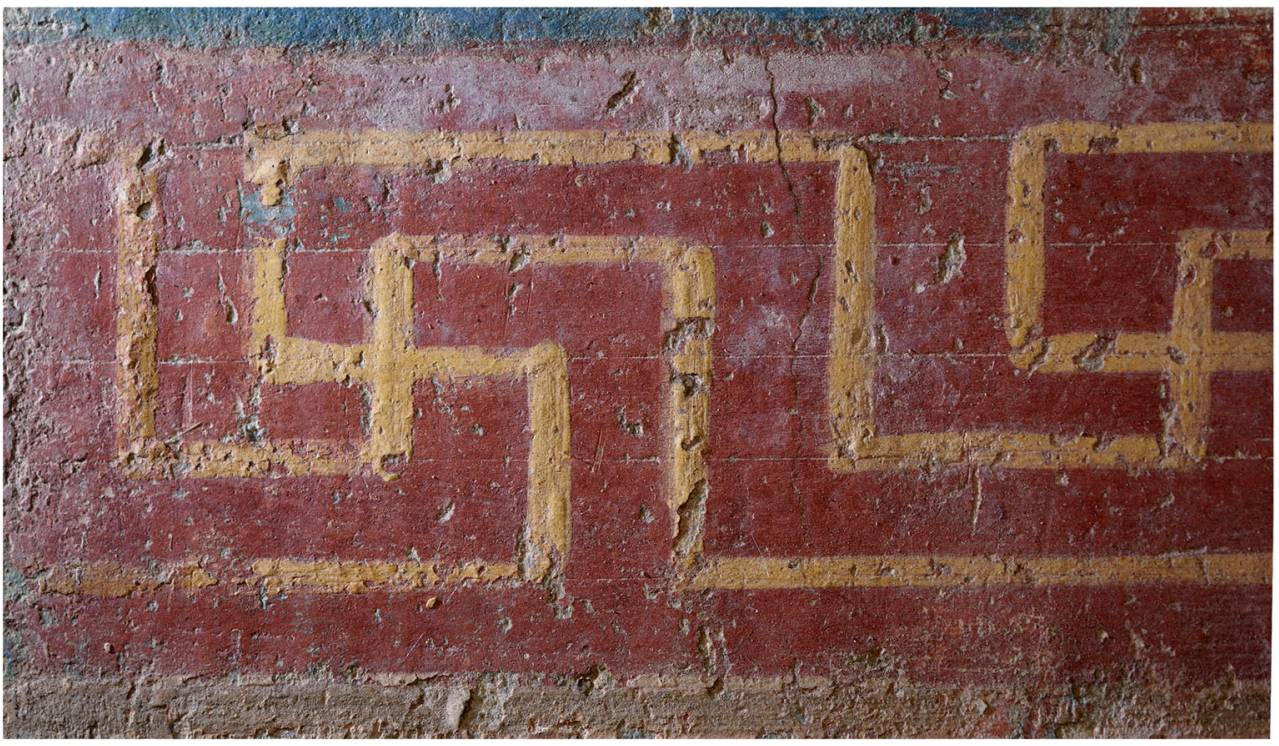

a

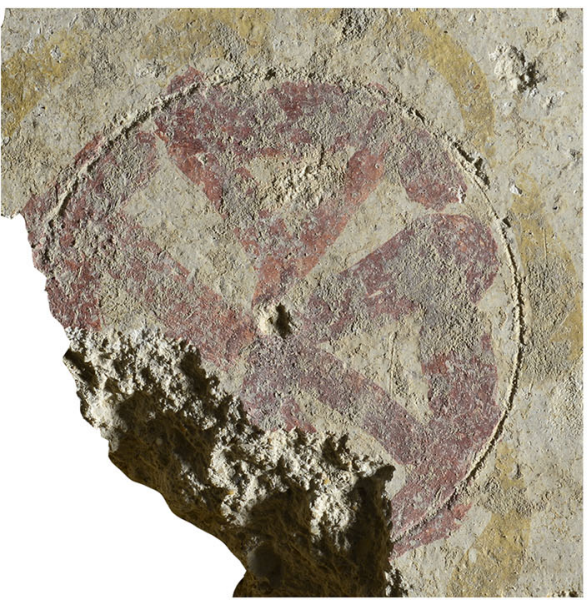

b

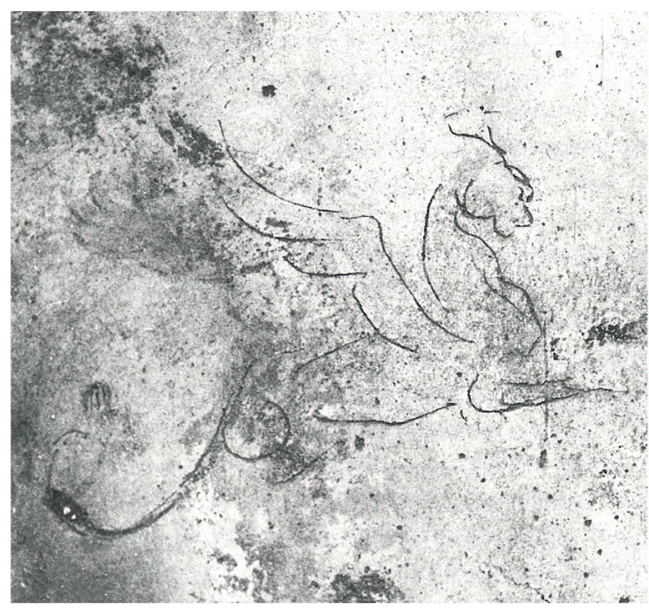

C 
firmitatem et splendorem et ad vetustatem permanentem virtutem poterunt habere."4) (Barbet 1998; Barbet 2000; Esposito et al. 2011).

Frescoing consists of applying colours thinned in water "a fresco" directly over damp plaster, while in drying, the plaster "incorporates" the colours, creating a compact and resistant film of calcium carbonate. This process, called lime carbonation, is caused by the reaction between the plaster's slaked lime and the air's carbon dioxide $\left(\mathrm{Ca}(\mathrm{OH})_{2}+\mathrm{CO}_{2}=\mathrm{CaCO}_{3}+\right.$ $\mathrm{H}_{2} \mathrm{O}$ ). Evaporation of water from the plaster mixture causes calcium hydroxide $\left(\mathrm{Ca}(\mathrm{OH})_{2}\right)$ to migrate towards the surface of the wall and, after crossing the paint film, react with carbon dioxide $\left(\mathrm{CO}_{2}\right)$ and form calcium carbonate $\left(\mathrm{CaCO}_{3}\right)$ (Vlad Borrelli 2015). The fresco technique therefore makes it possible to create wall paintings that are stable and long-lasting. In order for this to happen, however, decorations are to be painted very quickly on damp plaster. Coarse or defective painting on a nearly dry plaster leads to a progressive deterioration of the fresco, which tends to flake off while the colours lose their intensity.

In order to complete the details of the decoration on an almost completely dry wall, craftsmen used the a secco or mezzo-fresco techniques. In the first case, overpaintings (sovradipinture) of pigments mixed with different types of organic binders were added once the plaster was completely dry. In the second case, the carbonation process was reactivated using a "lime painting" technique, that is, mixing the pigments with slaked lime or limewater (Mora and Philippot 1999; Piovesan et al. 2012).

Once all the details of the decoration had been completed, the wall was smoothed (politiones) to compact all the layers of colour and make the painted surface shiny.

Vitruvius and Pliny also report that walls painted using cinnabar pigment were then subjected to waxing procedures. For a long time, this evidence has led to the theory that ancient paintings were encaustic paintings (Schiavi 1957-1958, 1961). The two Latin authors actually advised to apply wax to walls painted using cinnabar because they were aware of the instability of this pigment, which turns black when exposed to light (Sampaolo 2009).

\section{Pontate ("scaffoldings")/giornate ("working days")}

Wall paintings were executed top-down in order to prevent mortar or colour from damaging the decoration already

\footnotetext{
4 "Stucco, therefore, when it is well made, does not become rough in lapse of time, nor lose its colours when they are dusted, unless they have been laid on carelessy and on a dry surface. When, therefore, stucco has been executed on walls in accordance with these instructions, it will retain its firmness and brilliance and fine quality"-F. Granger, Trans.
}

completed (Fig. 5). The tector prepared and laid on the tectorium, and the pictores parietarii drew the decoration's compositional lines on the plaster and began to apply the colours of the background. When creating complex decorations or painting large rooms, the craftsmen worked in zones and applied as much plaster as required by the amount of work they thought they would complete in a day. On the frescoed wall, it is possible to detect both the giornate (working days), namely the daily layers of plaster which correspond to the vertical breaks in the decoration or to the outline of complex figurative elements, and the pontate (scaffoldings), the horizontal breaks corresponding to the position of the scaffolding. Generally, the pontata coincides with the transition between two zones (between zone 1 and zone 2 or between zone 2 and zone 3 ) and was cleverly masked through the elements of the decoration, such as cornices, friezes or predellas.

Once the pictores parietarii (wall painters) had drawn the decoration's outline and painted the simplest elements (architectural motifs, repertoire, etc.), the pictor imaginarius (figure painter) executed the most demanding and complex representations. He was the most skilled craftsman of the team and was in charge of painting large human figures or mythological scenes in the centre of the walls, using templates and sketchbooks to imitate famous models inspired from great easel paintings (Eristov 1987; Varone 1995).

Panel pictures could be executed either in the painters' workshop or directly in situ. The paintings produced elsewhere were mounted on wooden frames which were then set into the wall (picturae excisae Vitr. arch. II 8, 9; abaci...ligneis formis inclusi Vitr. arch. II 8, 10; excisum opus tectorium Plin nat. XXXV, 154 à XXXV, 45, 154 and 173 à XXXV, 49, 173). This is the case, for instance, of the painting with Cupids at work found in House V, 18 in Herculaneum (Maiuri 1938, 1940) inserted into a box approximately $2 \mathrm{~cm}$ deep, or of the paintings with Dionysian subjects with wooden frames in the walls of the hall (16) of the House of M. Lucretius Fronto in Pompeii (V 4, a). "Negative evidence" of the presence of such framed wooden panels are instead the empty slots "saved" for later setting paintings in the atrium (24) of the Praedia of Iulia Felix (II 4, 3) and in the salon (q) of the House of the Vettii (VI 15, 1) (Salvo 2018). On the other hand, in order to realise such paintings directly in situ, the pictor imaginarius laid on the intonachino over the portion of the wall that had been spared on purpose by the pictores imaginarii during the plastering and executed the painting. In this case, a slight undercutting can be seen around the perimeter of the painting.

These examples and the retrieval of work tools and cups with pigments in some of Pompeii's buildings (House I 9, 810; Taberna Attiorum IX 2, 11-12 - Esposito 1999; Borgard et al. 2003) are evidence to the existence of places used as 
Fig. 5 Schematic partition of the wall (Salvadori et al. 2015, p 53)

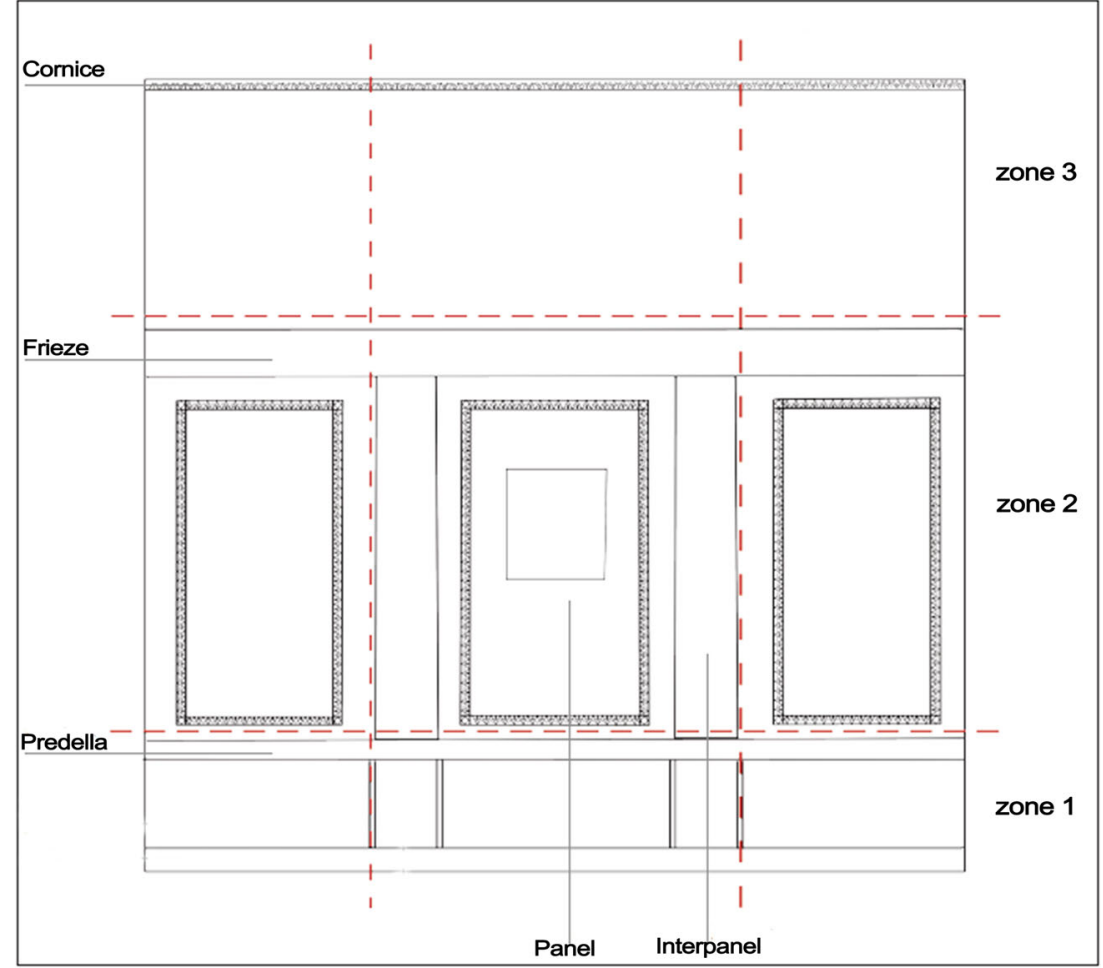

painters' workshops or studios, where they could execute paintings in wooden boxes, store their tools or prepare the colours to take to their work site (Esposito 2009).

That the pictor imaginarius was of a higher status was also legitimised in antiquity by the Edictum de pretiis rerum venalium issued by Diocletian in $301 \mathrm{AD}$ (an edict aimed at fixing the prices of various goods and services).

Ed. de pretiis 7 (de mercedibus operariorum)

8 Pictori parietario ut supra diurni denarios septuaginta quinque

9 Pictori imaginario ut supra diurni denarios centum quinquaginta.

The edict states that the pictor imaginarius was paid twice (150 denarii per day) the pictor parietarius (75 denarii per day) and the other workers in the workshop (Polichetti 2001; Plisecka 2011).

As far as these artisans' tools are concerned, pictores and tectores used various instruments. The basic equipment consisted of a mason's trowel (trulla) and float (liaculum) for applying and smoothing the plaster, a chalk-line, sharp tools for incising preliminary sketches on the wet coat, brushes (penicillus) of various sizes, mainly made of pig bristles, a plumb bob, rule and line, a set square, compasses and cups and amphoras' fragments for containing and diluting the pigments (Ling 1991; Ling 1999; Donati 1998; Barbet and Allag 2000) (Fig. 6a, b).

The most sensational archaeological evidence of how a fresco was executed is room (12) of the House of the Painters at Work (IX 12,9) in Pompeii. The house was in fact undergoing a renovation when the Vesuvius erupted (in 79 $\mathrm{AD}$ ), and in room (12), it is possible to see the different stages of the work when this was still in progress before being suddenly interrupted by the volcano. Zone 2 and zone 1 are incomplete indeed (Fig. 7) (Varone 1995; Varone and Béarat 1997).

Probably, two or three apprentices were preparing the mixture for the tectorium, while at least three or four painters were completing the decorations of zones 1 and 2. Along the eastern wall, some architectural views were about to be executed, as suggested by preparatory drawings made in yellow ochre and incisions. Moreover, on the eastern side of the southern wall, some a secco paintings (sovradipinture) were in progress. In the north-western corner, the intonachino had just been laid on to apply the black background colour. A pictor imaginarius was working on a mythological painting in the centre of the northern wall: he had already made the sinopia and was beginning to spread the colour (Esposito 2016a). The vertical joints visible in zone 2 indicate that the elaborate architectural perspectives had been completed by a painter who was more experienced than the one who had executed the simple monochrome panels in the middle zone (Varone 1995; Varone and Béarat 1997; Esposito 2016a)

Two sets of small bowls containing pigments were found in the room, that confirms that the work was carried out by several hands simultaneously (Bragantini and Sampaolo 2009, p. 30). 
Fig. 6 a Cups with Egyptian blue (Pompeii MANN inv. n. 117338) and red ochre (Pompeii MANN inv. n. 112265). b Plumb bob (Pompeii MANN inv. n. 76661), compasses (Pompeii, IX 8,7) MANN inv. n. 118226) and set square (Vesuvian area MANN inv. n. 76689) (Donati 1998 pp 201-206)
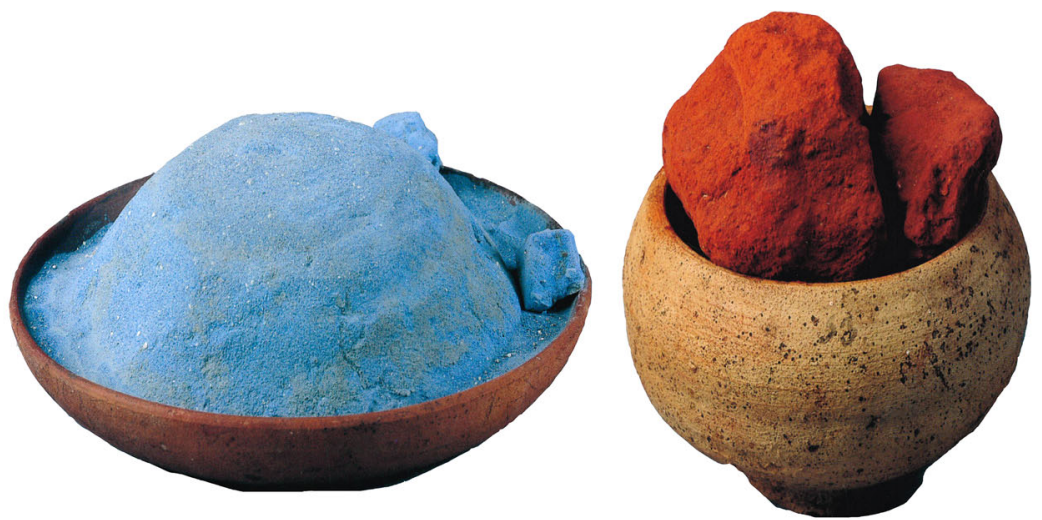

a

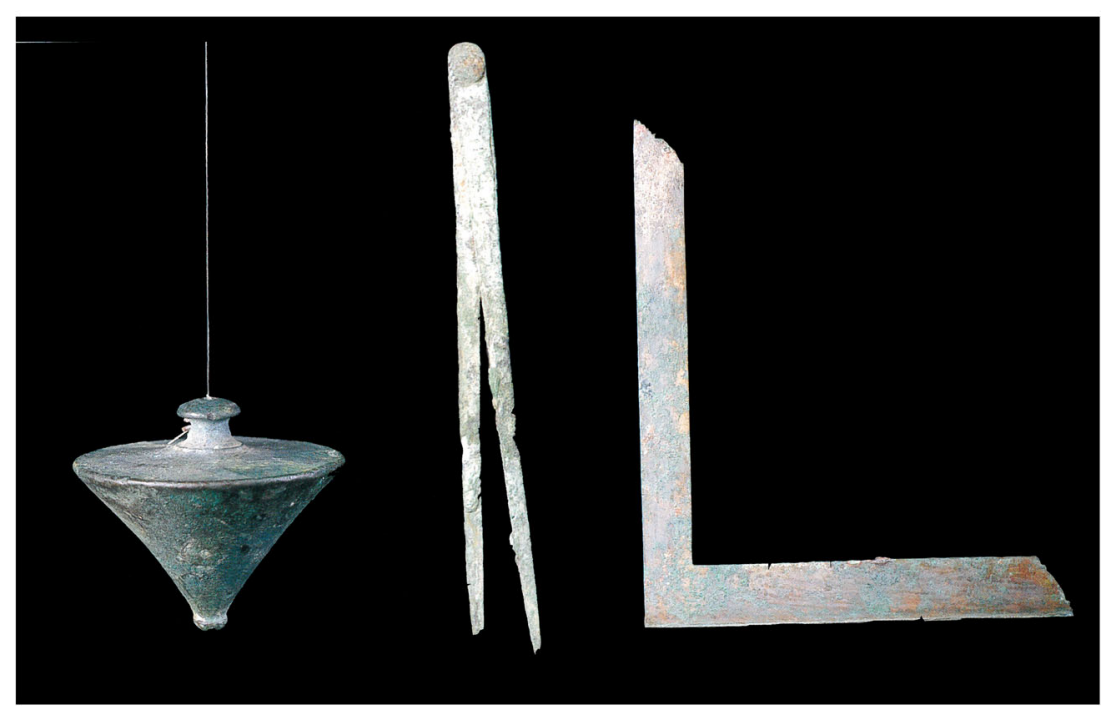

b
Fig. 7 Casa dei Pittori al Lavoro (IX 12, 9), Pompeii, room (12) east wall (Esposito 2016a, p 178)

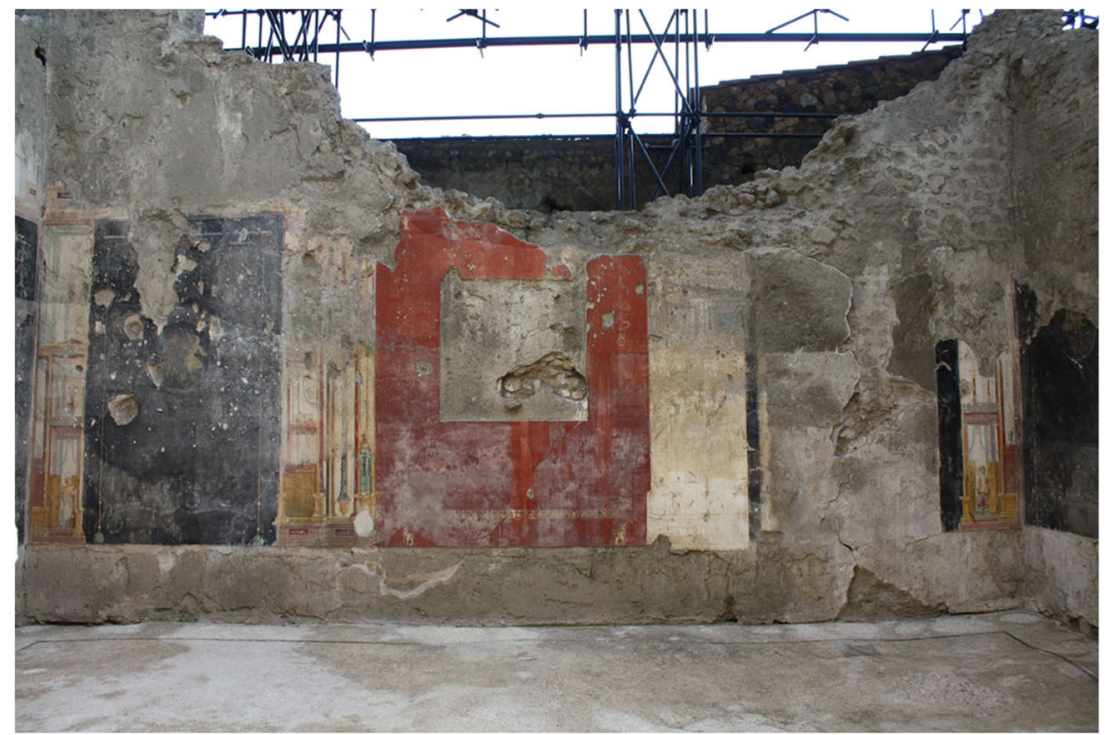




\section{Decorative schemes}

\section{The styles of Roman painting and Mau's theory}

Chapter V of the book VII of Vitruvius' De Architectura has represented a fundamental reference for the chronotypological classification of the paintings that have come to light in Pompeii and, more in general, in the area buried by the eruption of Mount Vesuvius in 79 AD. This classification was developed by the German archaeologist August Mau at the end of the nineteenth century (Mau 1882).

Basing on decorative schemes, coating techniques and figurative subjects, Mau codified four "styles" termed as (1) incrustation style, (2) architectural style, (3) ornamental style and (4) last style. Although successive revisions have been imposed by the development of studies in Roman wall painting, today Mau's reconstruction is still substantially valid (Bragantini 2014).

First, his chrono-typology considers Pompeian painting as an artistic phenomenon strongly conditioned by technique (i.e. the fresco, which requires rapid execution) and craftsmanship.

Second, Mau's approach highlights the link between wall painting and architectural context and emphasises its "architectural function". Starting from the art-historical perspective typical of his days, he ends up to propose an archaeological reconstruction, that is, he refers to the characteristics of the archaeological contexts.

The decorative repertoire of the so-called styles is varied by the craftsmen as to meet the precise requests and needs of the patrons. It is worth noting that Mau uses the term "system", which, in recent times, has been considered to be more appropriate as it expresses more clearly the link between the material (the wall painting), the architectural context and the craftwork's function, which mirrors the needs of the patrons (Salvadori 2012).

In reconstructing the evolution of Roman wall painting, Mau highlights the importance of the phase between the end of the second century and the first century BC, when a crucial change in houses' decoration fashion trends occurs that responds to the changes in Roman society, now strongly influenced by the conquest of Greece and Asia Minor. This leads to the abandonment of the stucco relief typical of the first style in favour of the exclusive use of frescoes. Complex decorative systems with illusionistic architectures (inspired to Hellenistic models) spread out in the houses of the members of the nobilitas and characterise the large state rooms: this is the so-called second style.

With the establishment of the Principality of Augustus (27 $\mathrm{BC}-14 \mathrm{AD}$ ), the decorative and figurative language of the second style is abandoned in favour of a sober and "classicistic" system. In the third style, or ornamental style, large figurative paintings stand out against monochrome walls decorated with refined ornaments - their mythological themes suiting the atmosphere of the new political order. This change in houses' interior decoration is closely related to the changed political and social conditions, to which the craftsmen seem to offer a concrete response.

The first half of the first century $\mathrm{AD}$, a widening social class being able to afford decorative and figurative systems for their houses, saw the development of the fourth style, or last style in A. Mau's nomenclature.

The decorative choices during Nero's Principate (54-68 $\mathrm{AD}$ ), characterised by the richness of the materials employed in the wall coverings (especially in the use of marble slabs), lead to a loss of interest in wall painting among patrons at the highest level of the social hierarchy and, consequently, to the disappearance of a coherent and shared repertoire.

While the general approach of Mau's study can still be accepted from many points of view, research has advanced in the last 30 years. Today, archaeological evidence is investigated not only in terms of formal aspect, but also in terms of semantic content, which proves the social imagery linked to precise choices of the patrons (see synoptic table).

\section{First style ("incrustation") and its antecedents: masonry style, "zero" style}

The so-called first style or "incrustation style" in Roman painting, documented from the middle of the second century $\mathrm{BC}$, is usually interpreted as an "Italic version" of the socalled masonry style or Greek masonry style (Hinks 1933; Bruno 1969). This aims at reproducing using painted plaster and stucco the architectural elements and ornamental features of the opus quadratum - what suggests a clear inspiration by the construction models of the classical period.

The earliest known evidence of masonry style is in Greece and dates probably to the end of the fifth century $\mathrm{BC}$, as proved by the stucco and plaster fragments found during the archaeological excavations in the agora of Athens, of a building of unclear interpretation, dating at least to the last decade of the fourth century BC (Bruno 1969; Guldager Bilde 1993). Since the end of the fourth century BC, this system of wall decoration spread out widely both in public complexes and luxury private houses. In the last 30 years, the increase of available documentation has allowed to identify the iteration of a series of architectonical elements like plinths, orthostats, rows of ashlars and cornices, within a wide range of solutions. These elements were shaped in stucco so as to stick out from the wall and recall the architectonical elements' structural function.

This attention to the mimetic rendering of the wall's threedimensional elements, which has suggested to someone to refer the invention of this decorative system to architects rather than painters (Bruno 1969), is combined with an attention 
to chromatic contrasts, obtained by combining monochrome backgrounds with panels imitating precious marble.

With reference to public buildings, emblematic is the decoration of the hall of the Hieron of Samothrace (Greece), mainly dating to the last quarter of the fourth century BC. According to P. W. Lehmann's reconstruction (Lehmann 1969), the series of black-painted orthostats covering the lower part of the wall and crowned by a red band with black veins were overlapped by alternating rows of wide and narrow red and white ashlars with red veins, bordered at the top by a jutting frame.

In the upper part of the wall, the inclusion of a further level consisting of a loggia of small Doric pillars sticking out over a row of marble-like panels is an innovative solution. Its aim is to produce an illusionistic effect. Two examples can be found in Delos in the House of the Comedians and the House of Dionysus (Bezerra de Meneses 1970), where in the gaps between the stucco pilasters a coffered ceiling painted in perspective along the upper edge is reproduced. Another example in the Vesuvian area is provided by the first style decorative system of the Casa Sannitica in Herculaneum (late second century $\mathrm{BC}$ to early first century $\mathrm{BC}$, atrium), where the series of semi-columns is connected to a protruding balustrade with crossed laths in the upper area (Guidobaldi and Esposito 2012).

While the example of the Hieron of Samothrace is evidence of a mature use of the masonry style in a public building, the evidence relating to domestic buildings in the late Classical period testifies to a rather basic approach. In this regard, the wall decoration of the houses in the city of Olinto (Greece) (Robinson and Graham 1938), founded in $432 \mathrm{BC}$ and destroyed by Philip of Macedonia in $348 \mathrm{BC}$, is very significant. In most rooms, which seem to have no wall paintings, the use of hydraulic plaster is documented in the bathrooms, while monochrome and polychrome plaster coverings are only attested in important rooms such as the andron (men's room) and the pastas (long porch or room fronting more than one other room) (Bruno 1969).

The houses of Olinto document two main decoration types. The first one is very simple and consists of uniform monochrome panels (white, beige and, in the best cases, red), while the second type is characterised by a chromatic bipartition between the plinth, that is most often white, and the middle area of the wall, which is usually red. Besides those types, a third one is documented that presents an additional zone between the base and the median area, often rendered in a contrasting colour or simply separated by an incised line. Rather than the masonry style, the walls of Olinto lacking any real projecting elements are ascribed to the so-called Stile a Zone (zone style).

The evidence of domestic decorative systems dating from the end of the fourth century BC to the third century BC is still limited; nonetheless, the few evidence refer to this phase show tendencies fluctuating between the masonry style and the Stile a Zone, i.e. the tendency to organise the wall into horizontal sectors in contrasting colours and the desire to reproduce an isodomic wall, also by using stucco to render the projecting parts.

Paradigmatic is the reconstruction of the wall of the socalled House of the Coloured Plaster in Pella (Macedonia), dating to the late third century BC (Fig. 8a). The surface of the wall is divided into two parts (Pontrandolfo 2002). In the lower part, a closed wall with orthostats, ashlars and jutting cornices is reproduced with a balanced colour scheme (white, red, blue and yellow). Instead, the upper part features a threedimensional balustrade with a portico modelled in stucco and open towards a fictitious outdoor space rendered through monochrome blue panels. This evidence proves that the masonry style achieved a more sophisticated elaboration in

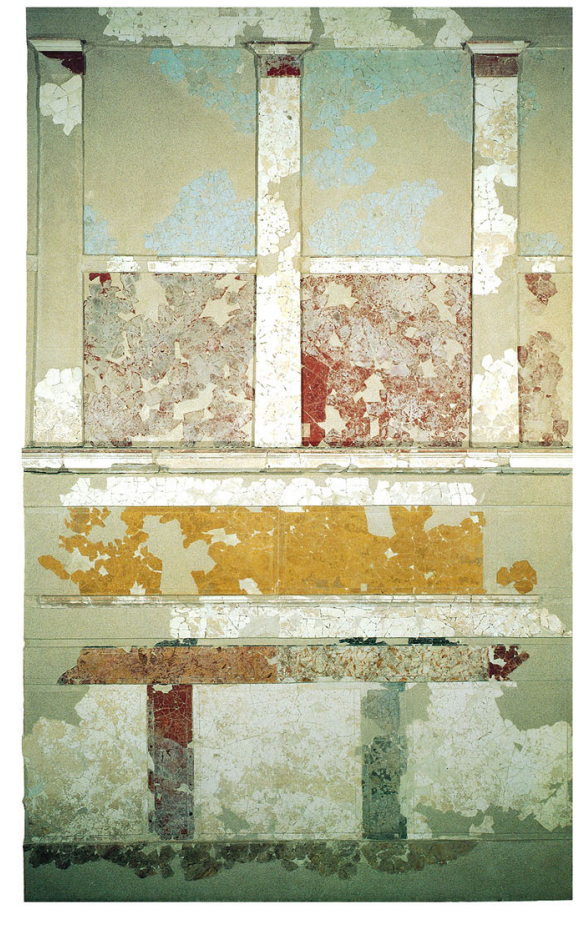

a

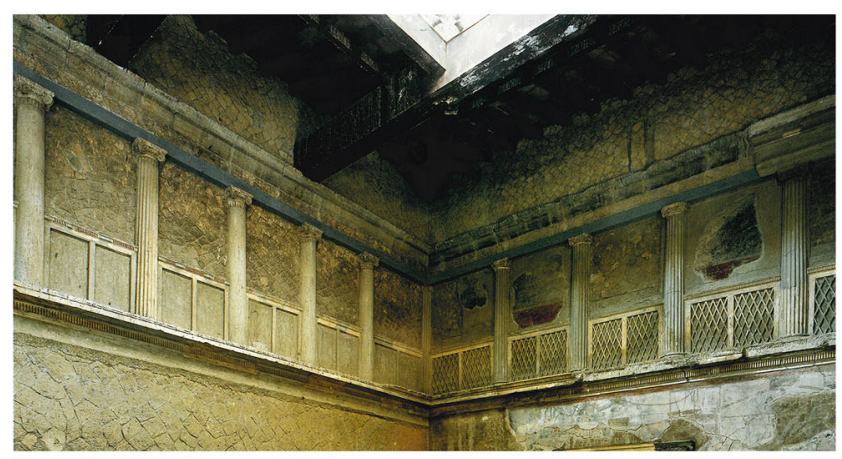

b

Fig. 8 a House of the Colored Plaster, Pella (Baldassarre et al. 2002 p 69). b Casa Sannitica, Herculaneum (Mazzoleni et al. 2004, p 59) 
Macedonia's domestic spaces, as well as in funerary monuments.

The successful development of the masonry style in the eastern Mediterranean is clearly documented by the wall paintings in the houses of the Greek sixth century settlement of Panticapeo (today Kerč, in Crimea), dating to the second century. In one of the houses discovered on Mount Mithridates, the wall decorations are very elaborate. Horizontal bands in the form of kymatia (moulding), vegetal friezes and cornices with meanders and denticles, either plastically modelled or just painted, sit on top of rows of orthostats, with projecting edges variously rendered in yellow, red and black to imitate polychrome marble coverings (Rostovtzeff 2003 [1913-14]).

In the western Mediterranean area, significant archaeological records have been found in Sicily (Italy). In Morgantina simple wall decorations are documented whose chronology is uncertain, oscillating between the middle of the third century BC to the middle of the second century BC (La Torre 2011). There are monochrome bases (red, white, blue or brown) and, above them, a horizontal band painted in a contrasting colour and two or three rows of blocks with incised margins imitating coloured or veined marble surfaces, closed along the upper margin by stucco frames.

The absence of orthostats in the lower part of the wall suggests to refer these systems to the Stile a Zone. The wall decorations of the houses in block II of Heraclea Minoa (dating between the end of the fourth century and the second half of the third century BC-De Miro 1966; La Torre 2011), in Lilybaeum (Casa via Sibilla - Griffo 2008) and in Finziade (today Licata) are to be ascribed to this system as well.

In particular, the decorative systems of Licata's House 1 seem to suit and reflect different functions of the rooms, dating between the end of the third century and the first decades of the second century BC (La Torre 2011). The rooms at the ground floor, arranged around a central courtyard, present an essential decoration in stucco to be referred to the Stile a Zone (red base and white middle zone framed at the top in moulded stucco ). The rooms of the so-called piano nobile (principal floor) instead should have been decorated with a more elaborate system, a sort of simple masonry style, with rows of overhanging blocks and linear cornices but also kymatia in polychrome stucco, sometimes in association with painted friezes with floral motifs. A step forward is documented by the peristyle house of Monte Iato, featuring polychrome marble-like orthostats that are rather typical of the so-called first style. The vast extension and decorative complexity of the building as compared to the simpler courtyard houses of Licata testify to the emergence of a new aristocratic class around the middle of the second century $\mathrm{BC}$. This phenomenon was largely encouraged by the development opportunities (including cultural development opportunities) underscored by the establishment of the Roman Province of Sicilia.
As for the Italian peninsula, the Stile a Zone and/or masonry style is documented by the fully mature evidence in Apulia (Italy). Residential buildings dating as early as the end of the fourth to beginning of the third century $\mathrm{BC}$ present decorative systems characterised by, from bottom to top, low bases, rows of jutting orthostats, horizontal bands, sectors with marbling and cornices moulded in polychrome stucco (ovolo, kymatia, palmette). The so-called Montarozzi house and the context of San Vito di Salpi (both in Apulia) are emblematic featuring, according to the description made at the time of the discovery (Marin 1964), the usual overhanging elements and an upper register decorated with semi-columns and a Doric frieze.

As regards houses' wall ornament in the Roman-Italic area, important data come from the latest surveys in the Regio VI of Pompeii (Pesando 2011), where the mid-Republic decorations reveal remarkable similarities with those of the Etruscan-Italic and Campanian tombs of the late fourth and early third centuries BC. The decorative systems of the Protocasa del Centauro (VI 9, 3-5), for instance, comprised a high monochrome base (yellow or red) extending approximately for two thirds of the wall or even more, crowned by a frieze with a stylised sea wave. The upper part of the wall had no decorative elements; it seems to have featured nothing but white background, while in many funerary contexts this part of the wall usually hosts figurative motifs.

The definition of Stile Zero has been proposed drawing on similarities with tombs' decorative systems, including the tomb of Ardea (in the south of Rome-Torelli and Marcattili 2010), which is particularly close in style, and find a comparison in Pompeii's house I, 5, 2, which dates to the end of the fourth century BC (Brun 2008). Stile Zero is the style of the prestigious rooms of Campania's aristocratic houses - a sort of "national" style of Etruscan origin, as suggested by M. Torelli-whose origin seems to be contemporary with that of the masonry style in Greece. The zero style is characterised by a bipartition of the wall into a high socle and an upper area and by the preference for a plane structure without any frames or relief elements.

Overall, the masonry style includes some variations that can be considered characteristic of the first style, introduced into the Italic peninsula. With the introduction of a high base between the plinth and the orthostats, the illusion of a real wall with regular and squared elements gets lost. The base looks like empty and meaningless since, being inserted underneath the orthostats, these are thus deprived of their "supporting" function and reduced to purely decorative elements. Painters working in the Italic context created a new type of wall decoration essentially leveraging its own ornamental effects but far from the constructive principles of the masonry style whose repertoire of forms and motifs modelled in stucco it still inherited.

This is a severe style, inspired by ancient Greek paintings, very close to the Roman concepts of gravitas and mos 
maiorum (cult of the ancestors). Indeed, in some Pompeian houses' rooms, wall paintings in the first style were preserved even in buildings that underwent a refurbishment at a time when this style had already gone out of fashion. This conservation choice is quite common in the fauces (the entrance corridor), where first style decorations were usually preserved as evidence of the domus' antiquity. Paradigmatic is the case of the Casa Sannitica in Herculaneum (late second century BC), where the fauces (Fig. 8b), the atrium (hall) and the tablinum (large room at the rear of the atrium) had maintained the original impressive first style decorations despite the general renovation of the paintings in the other rooms. In particular, the large atrium's superior register is decorated with an impressive stuccoed loggia of ionic half columns connected through a crisscross balustrade (Mols 2005; Guidobaldi and Esposito 2012).

The most remarkable example, however, is that of the Casa del Fauno (VI 12,2) in Pompeii, one of the city's most ancient and distinguished residences, extending over an entire insula for $2970 \mathrm{~m}^{2}$ (PPM V). Some of the house's "state rooms"'s first style wall decorations remained untouched from the last decades of the second century $\mathrm{BC}$ to the eruption of Vesuvius in $79 \mathrm{AD}$, when they were still thought to add to the house's prestige. Particularly interesting is the entrance vestibule (fauces), whose coloured marble-like decorations were visible from the street without neither crossing the doorway. The panels in the middle zone are to simulate precious alabaster; nonetheless, their mottled pattern and lithotypes do not exist in nature. On the upper part of the wall, four small Corinthian columns rest on protruding corbels in front of an illusionistic façade with a monumental portal in the centre that evokes a temple. After crossing the fauces, the guest could then enter the large atrium, which was also embellished with first style decorations, the upper register suggesting a sort of second floor through a blind gallery with ionic stucco semi-columns.

The entire layout of the house reveals the adoption of a "Greek" lifestyle. Luxury and pleasure could be associated with the evocation of the heroic deeds of great leaders, as suggested by the presence of the above-mentioned mosaic of the Battle of Alexander against Darius (Pesando 1996; Zevi 1998).

\section{Second style ("architectural-illusionistic")}

Around the last decades of the second century BC, there was a radical transformation in Roman wall painting technique. The first style's repertoire of three-dimensional architectonical elements, marble slabs and frames modelled in stucco began to rather be painted on the wall in an illusionistic manner by playing with light and shadows, what proves Roman wall painters' impressive execution skills (Mulliez 2014; Beyen 1960). This new system of wall decoration is known as second style or architectural style according to Mau's terminology.

Due to its early date, an extremely relevant evidence is that of the Casa dei Grifi on the Palatine (Rome), discovered in 1912 by G. Boni during his explorations of the Domus Flavia. The domus' name, due to G.E. Rizzo, is inspired by the stucco decoration on the lunette of one of the two preserved rooms. Basing on building techniques, the first structure of the house has been dated to the last decades of the second century $\mathrm{BC}$; the wall decoration underwent later transformations around 90-80 BC. The original decoration system comprises a series of painted Corinthian columns resting on pedestals rendered in perspective occupying the central area of the wall and scanning a sequence of alabaster and porphyry-like panels and others with a pattern of cubes in isometric perspective (Fig. 9a). The upper part is characterised by an ashlar masonry and architectonical cornices that look like sticking out of the wall (Rouveret 2002b). The palette is dominated by a bright cinnabar red conferring the overall decoration vivid chromatic effects; this colour choice also reflects the ambition and luxury characterising the wall coverings themselves and suit the concrete materiality of the painted elements.

Early evidence of second style are documented also in northern Italy, namely in the four halls of the late Republican sanctuary of Brescia (Bianchi 2014). The elaborate wall decorations are conceived as closed surfaces and correspond to two different schemes. The best preserved one is that of room 4: the base features a richly curled velarium (drapery), while the middle section presents a series of rectangular polychrome pseudo-marble panels separated by bright red pilasters. The transition to the upper zone is marked by a cornice with perspective meanders, above which is a $* *$ fictious ashlar masonry. This scheme is further enriched by the replication of ionic column from which the wall looks like being positioned backword. This is an extremely high quality decoration whose value is further enriched by the heads of Medusa in the perspective meandering frame, which find comparisons in some Hellenistic houses on the island of Delos, and by the motif of the velarium, which occurs also in some second style wall paintings in Pompeii (e.g. Casa del Fauno, Casa di Cerere, Casa del Labirinto), but also in Sicily (Catania, Centuripe) (Baggio and Salvadori 2017).

Also the "closed" surfaces of panels scanned by columns or pilasters are characteristic of a considerable amount of wall paintings from the Vesuvian area that refer to the first phase of the second style. Later on, the upper part of the wall begins to extend towards an imaginary exterior by means of arches or small frontons open onto outdoor spaces where the top of sacred buildings emerges against the blue background of the sky. The back wall of cubicle (16) (bedroom) of the Villa dei Misteri in Pompeii (Fig. 9b), famous for its megalography, provides a very clear example of a perspective effect 
Fig. 9 a Casa dei Grifi, Rome. b Villa dei Misteri, Pompeii, cubiculum (16). c Villa of P. Fannius Synistor, Boscoreale, cubiculum (M) (Mazzoleni, Pappalardo, Romano 2004, p 67, 104, 81)

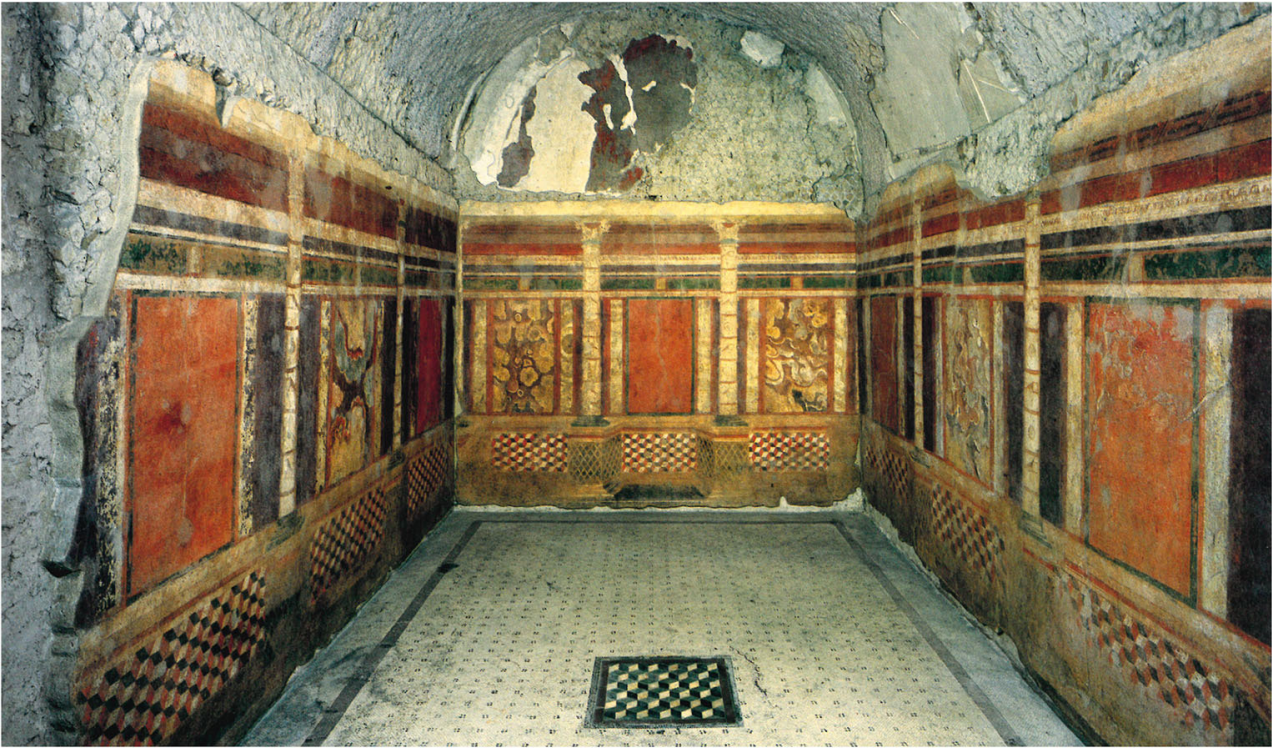

a

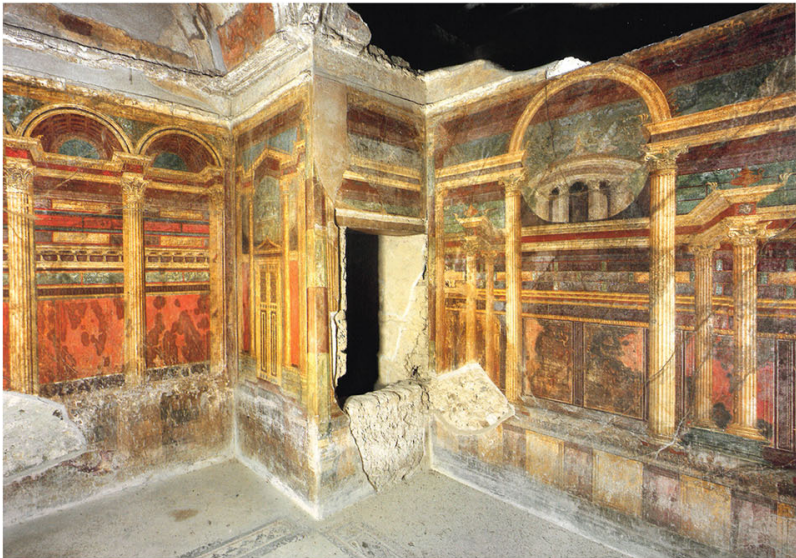

b

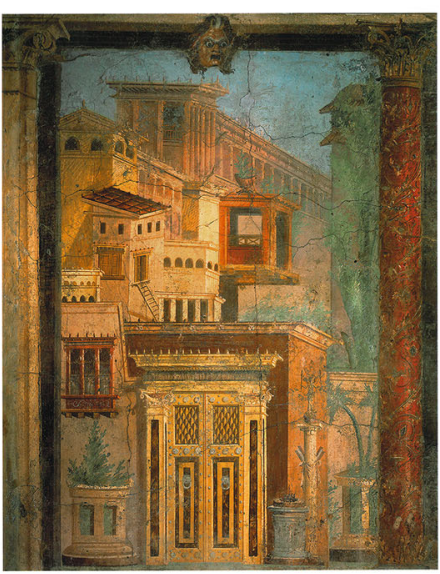

C articulated through four levels of deepness. The illusion is further emphasised by the relatively small size of the room as compared to the large reception rooms.

From the fourth decade of the first century BC, the compositions gradually become more varied. Podiums, colonnades and architectural structures rendered in perspective kind of "break through" the wall, beyond which further architectural or landscape spaces "become visible".

Paradigmatic of such a "deception" is the famous cubiculum (M) of the Villa of P. Fannius Synistor in Boscoreale (Naples) at the Metropolitan Museum of Art in New York (Fig. 9c). Here, a scenography-like set opens onto a series of urban and rustic panoramas arranged symmetrically in both sides of the room. This is likely the concrete transposition of Vitruvius' passage devoted to the three types of frons scaenae: tragic, comic and satirical (Vitr. arch. VII 5,2). The illusionistic spaces "beyond the room" occupy the entire middle area of the walls and create a fine effect by mixing natural and architectonical elements which seem to evoke sumptuous palaces or villas.

The close similarity between these trompe-l'oeil architectures and real theatrical scenography has been subject to numerous considerations by scholars (Tybout 1989). If it is undoubtedly true that the scaenographia (the backdrop of a theatrical stage) constituted a highly experimented pictorial genre in the ancient world, it is more difficult to understand what meaning Roman patrons attributed to such decorations in the context of their private life. One aspect seems to have been accepted that is the desire to simulate regal architecture through theatrical spaces.

In the final part of his famous text concerning wall painting in late Republican, Vitruvius focuses on two pictorial genres: topia and megalographiae (Vitr. arch. VII 5,2). The topia are early forms of landscape painting inspired by the development 
of a landscape aesthetics in the Hellenistic period, of which the hunting scenes of the façade of Philip's Tomb in Vergina (last decades of the fourth century BC) are one of the earliest examples. The megalographiae are large-scale representations of noble subjects, mainly inspired by mythical stories and characters or connected to the Greco-Roman cultural tradition and in particular to the events narrated by Homer (the author of the epic poems Iliad and Odyssey). The most famous examples of megalography are in the Villa dei Misteri in Pompeii and the Villa of Fannius Synistor at Boscoreale mentioned above. The understanding of these two large friezes raises a number of interpretative questions which we ought better to deal with in the paragraph dedicated to megalographiae.

Instead, it is worth dwelling here on the remarkable Pompeian example of the Casa del Criptoportico (I 6, 2-16). The wall paintings adorning the walls of the underground portico, executed around 40-30 BC, show a paratactic sequence of dark red monochrome panels marked by pilasters in the shape of male and female hermae placed on pedestals and supporting the stucco frames at the top of the wall. Above the panels, between the heads of the hermae, runs a frieze depicting episodes from the Iliad (Fig. 10a). The episodes succeed one another in a clockwise direction beginning from the entrance of the cryptoporticus through the whole $\mathrm{U}$-shaped room. The narration starts from the episode of the plague sent by Apollo upon the Achaeans' camp, followed by those of the exchange of weapons between Diomedes and Glaucus (the identification is confirmed by the names that label each character in all the scenes) and the duel between Diomedes and Aeneas. The frieze's episodes do not follow Homer's narration, the two scenes with Diomedes being reversed as compared to the Iliad. Among the other numerous episodes depicted in the frieze, that of the Thetis delivering Achille's weapons made by Ephestus training of Achilles' weapons by Hephaestus is worth mentioning. Thetis, engrossed in her thoughts, is depicted in a corner of the picture, according to an iconographic scheme that is completely different from that, more diffuse, of the Nereid looking at the fate of her son, reflected in Hephaestus' shield.

Not only does this frieze reveal the patrons and artists' high cultural status, but it is also an evidence of a combination of different literary traditions. The last scenes include the arrival of the Amazons, the subsequent duel between Achilles and Penthesilea and the final escape of Aeneas, Anchises and Ascanius indeed, which are no longer taken from the Iliad, but from the so-called cyclical poems (which dealt with the Homeric heroes and other minor heroes' adventures in the aftermath of the war) (Bragantini 1990).

Another extraordinary example of what Vitruvius defines as Ulixis errationes per topia (Vitr. arch. VII 5, 2), i.e. Ulysses' journey from place to place, is that of the portico of the Domus of via Graziosa in Rome (mid-first century BC).

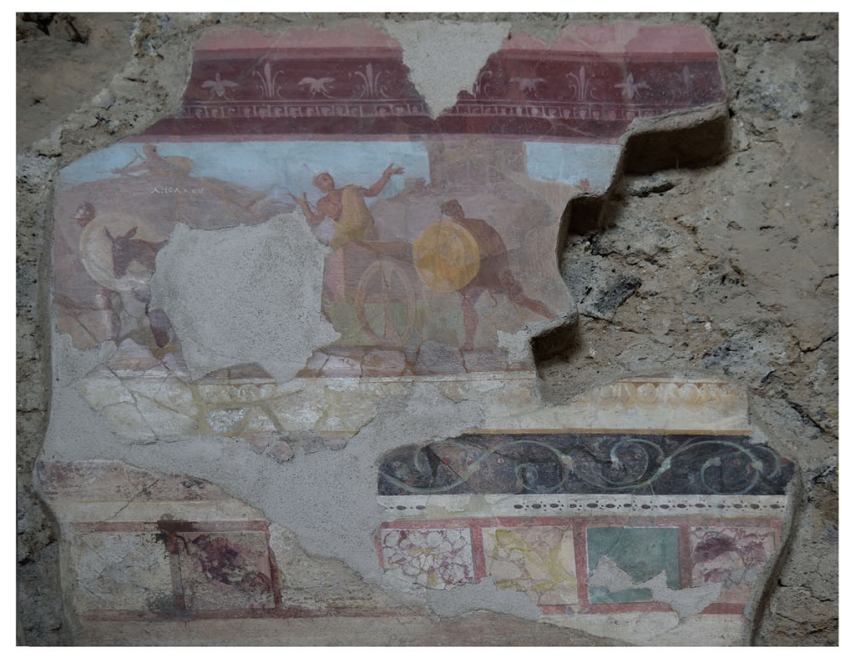

a

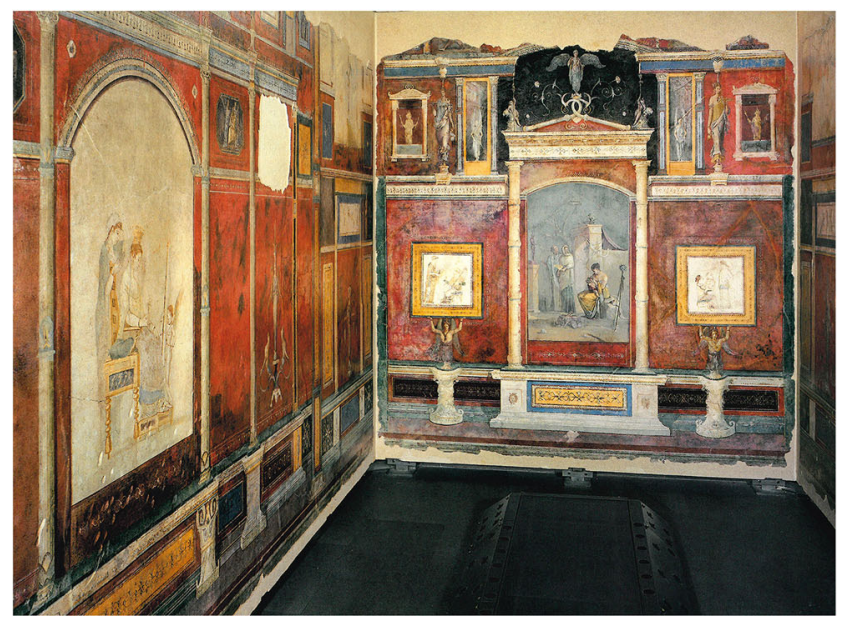

b

Fig. 10 a Frieze narrating episodes from the Iliad, Casa del Criptoportico (I 6, 2-16), Pompeii (photo by author). b Villa della Farnesina, Rome cubiculum (B) (Mazzoleni et al. 2004, p 211)

The epic scenes, today on view at the Vatican Museums, were once arranged along the upper part of a circa $5.50 \mathrm{~m}$ high wall, whose middle zone was marked by a sequence of black monochrome panels and red-painted pillars in the foreground. As in the Casa del Criptoportico, the Homeric scenes occupied the upper band of the wall and resemble a continuous frieze constituting an imaginary space beyond the room. The characters, identified by some inscriptions in Greek, are reduced to small figures in wide and bright landscapes with steep rocks, seashores and trees. The episodes accurately illustrate the Homeric poem and seem to focus mainly on the events that should have happened along the Italic coasts, including when Ulysses came to the land of the Laestrygones, the cannibal giants, his arrival at Circe's palace and his journey in the afterlife. With this frieze, the house owner was able to display his fascination with the Homeric tales to his guests, who could play with their fantasy and imagine 
the adventures of the ancient heroes as they contemplated the lively landscapes.

As far as the development of the decorative motifs is concerned, one notices a change in the architectural structure typical of the second style around 30 BC. Illusionistic threedimensional architectures tend to flatten out into bidimensional surfaces and to become slenderer, less realistic and more ornamental, to eventually reduce to sort of cornices that framed the large figured panels usually placed in the centre of the wall. The polychromy gets simpler and it is used only to highlight the meaningful images. Figurative scenes multiply over the walls, sometimes even evoking a picture gallery.

The fresco cycles of the urban imperial residences clearly illustrate this change with regard to both the overall design of the wall decorations and the new conception of the architectural elements losing reality, what was criticised by Vitruvius (Vitr. arch. VII 5, 3-4)

One of the clearest examples of this new fashion trend is the Villa della Farnesina, which has been associated to the marriage of Agrippa and Julia, Augustus' daughter. Its frescoes have been removed from the site and are now on exhibit at the Museo Nazionale Romano. Particularly interesting is cubicle (B) (Fig. 10b), featuring, along the walls of the antechamber and the alcove, a pinacotheca with paintings of different styles and on various supports.

The beautiful scene in the central aedicula (ornamental pavillo-like structure) - kind of an altarpiece ante litteram representing Ino-Leucothea breastfeeding the infant Dionysus in a Hellenistic-style landscape is accompanied on both sides by paintings with scenes of female paideia (education) on a white background and characterised by a classical-style balance. The relevance of these pictures (which look like painted on marble slabs) is emphasised through the elaborate polychrome frames and the statuettes of sphinx placed on elegant vegetal half columns that hold them. Overall, the entire decoration of the Villa della Farnesina is sort of an anthology of how paintings were displayed in private spaces, whether hung on, or inserted into, the wall, or resting on, or hold by, a support. One of the principal themes of the entire decorative cycle, almost a fil rouge linking the various rooms' wall paintings with one another, is that of the landscape. One of the most refined examples can be found on the walls of triclinium C. From the monochrome black walls scanned by miniature columns from which garlands were draped, vague landscapes emerge as if they were the product of the viewer's imagination (La Rocca 2004).

\section{Third style ("ornamental")}

In a few decades, the decorative features already in nuce in the last phase of the second style take over the entire wall, drastically reducing the presence of any architectural elements. With the disappearance of any illusion of perspective, it is possible to refer to the third style. This system begins to spread out around the last decade of the first century BC, when Augustus comes to power.

The third style conceives the wall as a plane surface and the canonical subdivision into base; the middle and upper part tends to reduce to a sequence of monochrome panels (usually black, red and white), delimited by simple and elegant ornamental frames.

Columns become slender poles, often "vegetalised", or are transformed into candelabra (Bastet and De Vos 1979).

Figurative panel pictures in the centre of the wall with only a few clearly defined figures are evidence of an aesthetic choice shaped by the desire for proportion and classical balance typical of the Augustan age.

In the first phase, which corresponds to the Principate of Augustus, the ornamental repertoire is rendered with extreme meticulousness, but it is rather limited and rather ancillary to the general effect of the overall decorative system, which appears simple and polished. With reference to the ornamental elements, Egyptian motifs are in line with the lust for "the exotic" and "the archaic" of the Augustan ruling class.

One of the most notable examples is that of the Villa of Agrippa Postumo in Boscotrecase in the Vesuvian area, dated to the last decade of the first century BC. The wall decorations of the three rooms are partly at the National Museum of Naples and partly at the Metropolitan Museum of Art in New York. Here, there are no references to illusionistic architectures, and the wall is rather characterised by the presence of large monochrome panels articulated by detailed and refined decorations.

The black walls of the cubiculum present slender candelabra supporting paintings with Egyptian scenes taking place on a yellow background (Fig. 11a). The central aedicule is composed of thin, almost metallic "columns" and frames small landscape views that look like cameos and evoke the landscapes of the Villa della Farnesina (Fig. 11b). Even more refined is the decoration of the so-called red room, whose monochrome bright red walls feature in the centre large pictures with "idyllic-sacred" landscapes on a white background (Fig. 11c). A third room, probably with white walls, was decorated with representations of mythological themes in natural landscapes, like Polyphemus' love for the nymph Galatea and Perseus freeing Andromeda (Von Blanckenhagen 1962).

A similar decorative system can be observed in the Villa Imperiale in Pompeii, where the oecus (saloon) A is decorated with large paintings of mythological landscapes and monumental scenes inspired by Cretan cycle, including Daedalus and Icarus, Theseus and the Minotaur and Ariadne at Naxos. The abundance of images in this large reception room, designed to express the culture of the patron and his passion for collecting, is further multiplied in the upper part of the wall 
Fig. 11 a Egyptian scenes, Villa of Agrippa Postumo,

Boscotrecase, "black room" (Baldassarre et al. 2002 p 155). b Small landscape, Villa of Agrippa Postumo, Boscotrecase, "black room" (MET inv. n. 20.192.1). c "Idyllic-sacred" landscape, Villa of Agrippa Postumo, Boscotrecase, "red room"

(Baldassarre et al. 2002, p 155). d Fall of Icarus Casa del Frutteto (I 9, 5-7), Pompeii (photo by author). e Insula 18, red room, Avanches (Musée Romain d'Avences) (Baldassarre et al. 2002, p 211)

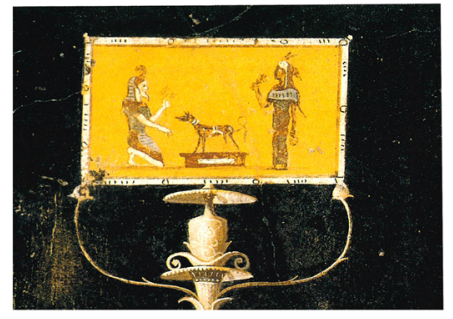

a

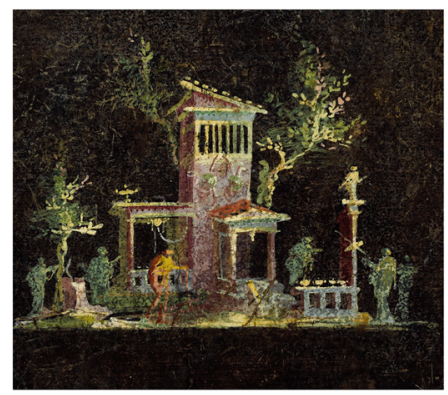

b
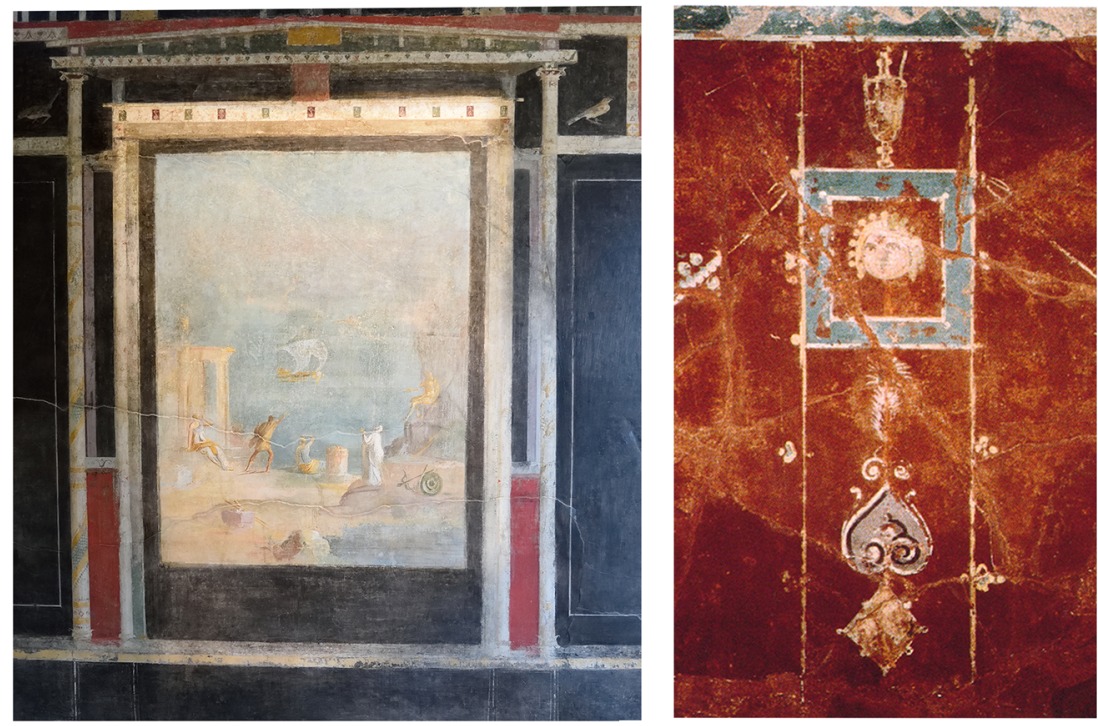

d

e by Dionysian representations and six small paintings (pinakes) with portraits of poets like Sappho and Alceus.

In particular, the theme of the Fall of Icarus seems recurrent in Pompeian decorations. It is represented in the form of a mythological landscape in the triclinium of the Casa del Frutteto in Pompeii (I 9, 5-7); here the mythological episode is set between sky and earth, thereby giving the painter the possibility to insert more details, such as the astonished spectators (Fig. 11d).

In a more advanced phase of the third style, in the first half of the first century $\mathrm{AD}$, the sober elegance that characterised the paintings of the Augustan and Tiberian periods is gradually abandoned. The palette of walls' colour becomes more varied, and the chromatic contrasts get more vivid. The decorative elements multiply and overlap with one another in fictious ways and overload the entire walls, which receive compositions of diagonal lines and convex, concave, oval and circular elements as well. In the upper part of the wall, they reappear slender architectures that invade also the middle zone, flanking the aedicule with the central painting (Bastet and De Vos 1979).

The decoration of the tablinum of the Casa di M. Lucretius Fronto (V 4, a) in Pompeii (Peters 1993) provides a clear example of this later evolution of the third style. The remarkable richness of the room is visible on the wall: the architectural elements typical of the second style reappear but emptied of their structural and realistic value; rather, they are transformed into ornamental elements. The decoration of the base 
represents a closed garden (hortus conclusus) with a gushing fountain in the centre on a black background. The decoration of the middle part of the wall instead plays on a series of contrasts, namely chromatic, size and content contrast, with central red panels hosting mythological paintings (the love stories of Mars and Venus and of Heracles and the triumph of Dionysus) flanked by black panels featuring landscape paintings of seaside villas on the Campania coast supported by elegant candelabra. The upper zone displays a complex scenography, whose architectural elements are distant from the realism of the second style though.

Lastly, it is worth remarking that the stylistic elements and wall decoration systems that distinguish the wall painting of the first half of the first century $A D$ in the peninsula find comparisons also in the provinces. The preference for an ever more complex and imaginative ornamentation and the use of plain backgrounds, very often monochrome and showing lively chromatic contrasts between the different parts of the wall, find an echo in the artistic choices of the workshops of painters operating in the different provinces of the Empire, especially in the transalpine area and the western extremes. As an example among others, we may cite the "red room" of Avenches (insula 18) (Fig. 11e), the ancient Aventicum, in Germania Superior, today's central Switzerland. The monochrome red walls of this room are scanned by twisted columns decorated with vegetal motifs and vegetalised columns from which ribbons and bunches of grapes are draped, as well as bands with elaborate ornamental motifs (Barbet 2008).

\section{Fourth style ("intricate")}

The innovative style of the Domus Aurea influences the wall painting of the second half of the first century AD and the subsequent periods, although recent studies date the first evidence of the fourth style before the reign of Nero.

From the mid-first century AD onwards, there is a revival of the architectural structures, often rendered in perspective, which does not influence the decorative structure of the wall though. This represents the main change from the canons of the third style. The superabundance and creativity of the fictious architectural frames is married to an overload of ornaments and leads to "baroque" compositions. The main characteristic of the fourth style is its eclecticism, which is likely a legacy of Fabullus, the painter to whom the literary sources attribute the frescoes of the Domus Aurea. He enjoyed a "Mannerist" manner for the use of contrasts, and according to Pliny, his style was, at once and the same time, solemn and severe (gravis ac severus) and brilliant and fluent (floridus ac umidus) (Barbet 1985 2009; Baldassarre 2002).

What survives of the majestic residence, which extended over eighty hectares, proves its stylistic uniqueness, which is due not only to the different functions of the rooms, but also to the influence of various painters. The high walls completely covered with multi-level façades, from which single or couple of figures emerge, are outstanding. The decorative elements and frames, especially in the vaults, are populated by fantastic figures and objects that are purely ornamental. It was this decorative richness that fascinated sixteenth-century artists and inspired to them the creation of the grotesques.

Large figured mythological tableaux are placed mainly on the vaults, especially in their centre. One example is room (119), the so-called Hall of Achilles at Skyros (Fig.12), which owes its name to the famous mythological episode in the centre of the vault. This is divided into false lacunars outlined by elaborate stucco frames and hosting vignettes or individual figures. The apsidal basin instead is decorated with a shell with ribs in relief and fanciful "grotesques" rendered through a profusion of various overlapping layers of colour.

The less important rooms have simpler decorative systems. The architectural façades are replaced by sequences of plain panels outlined by unusual, pierced borders and with small landscape paintings depicted with rapid brush strokes enlivened by white tones, based on light effects. This "impressionist" painting technique would then become the distinguishing stylistic feature of the late fourth style (Baldassarre et al. 2002; Meyboom and Moormann 2013).

The evolution of this style can be followed in the Vesuvian area, where due to the earthquake of $62 \mathrm{AD}$ the decoration of some rooms that had been damaged had to be restored.

In general, the chromatic contrasts between the various parts of the walls get more intense, and, in addition to the black, red and white backgrounds typical of the third style, there are also yellow and blue backgrounds. Most times, the decoration of the middle zone consists of a sequence of panels decorated with perforated borders (a sort of signature motif of the fourth style - Barbet 1981-Fig. 13a) and hosting in their centre "flying" figures or small pictures (Peters 1982).

In more elaborate contexts, these simple systems are replaced by complex constructions extending over the entire wall to form the background against which mythical events are staged. An example of this is cubicle (A) in the House of Pinarius Cerialis (III 4, 4.6); in the centre of a complex architectural façade, Iphigenia appears from beyond the portal of the temple of Artemis in Tauris, flanked on both sides by Orestes and Pylades, who are destined to be sacrificed to the goddess, and the Scythian king Toante, who has taken the two heroes prisoners.

One of the most remarkable examples from Pompeii, however, is that of the Casa dei Vettii (VI 15, 1), whose frescoes were executed by some of the finest painters of their days (Peters 1977; Esposito 1999, 2007, 2009). The median zone of the famous reception hall's walls is occupied by large red panels with flying couples in the centre, separated by vertical black bands (inter-panels) with gilded candelabra. Under it runs the frieze (predella) with genre scenes: cupids and psychai are engaged in various work and activities 
Fig. 12 Hall of Achilles on Skyros, Domus Aurea, Rome

(Baldassarre et al. 2002, p 226)

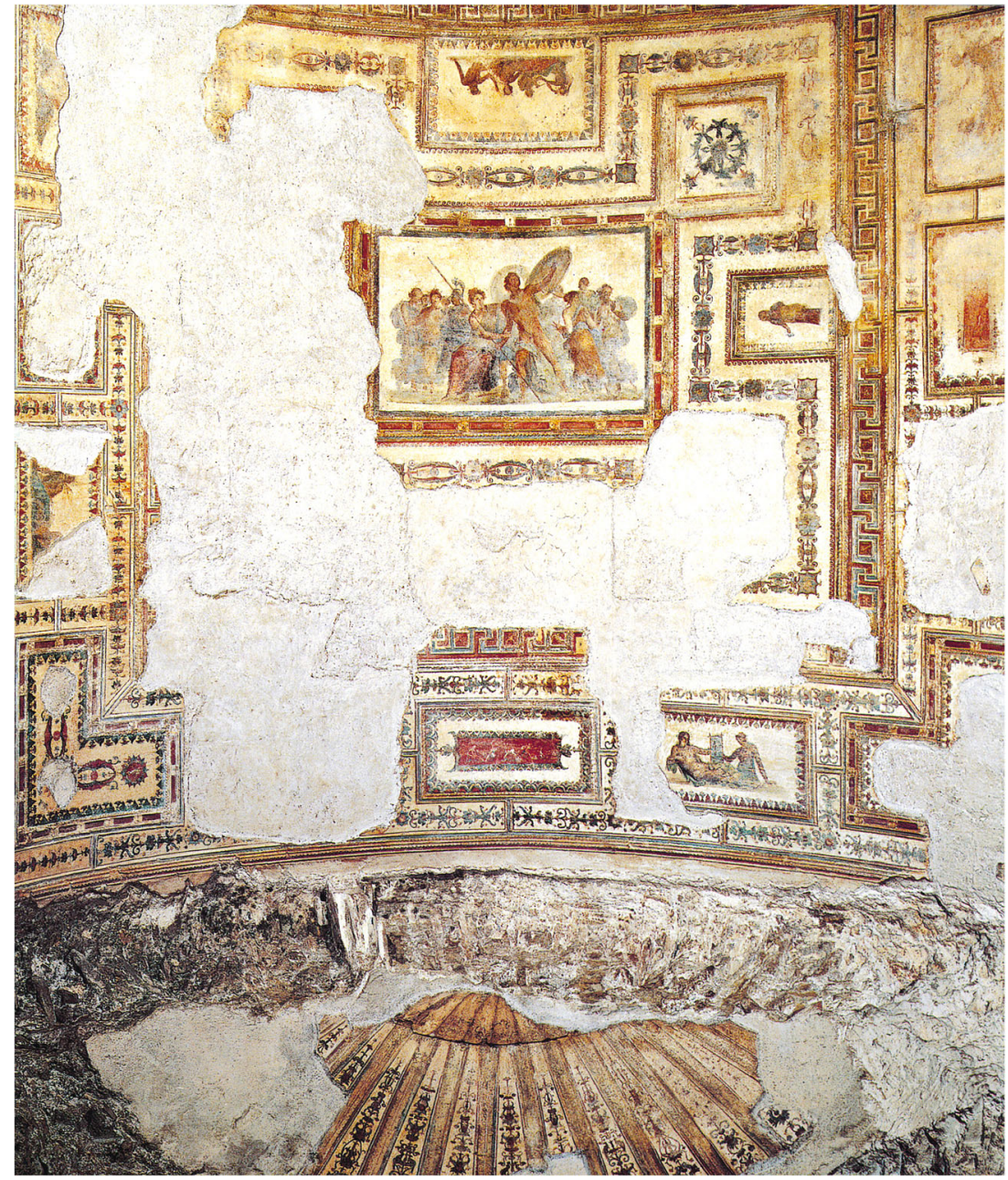

(Fig. 13b). The decoration of the southern triclinium is even more ambitious in terms of contents. Golden yellow panels alternate with architectural views standing out against light backgrounds; they host large mythological paintings, including Heracles strangling the snakes, Pentheus torn apart by the maenads and Dirce tied to the bull (Fig. 13c). These paintings are very emphatic(/pathetic?) and far from the classical soberness of the Augustan age; the walls' overall decorative exuberance is furthered by the proliferation of architectural perspectives. The superabundance of ornamental motifs is even greater in the decoration of the northern triclinium.

Different features have been recorded in the northern part of the Italian peninsula, in the Cisalpine and in the adjoining Gaul. In these provincial territories, the circulation of people and artists and the presence of Roman notables entailed an early acceptance of traditional decorative systems in Roman wall painting. Therefore, when in the middle of the first century $\mathrm{AD}$, Rome and the south converted to the extravagant features of the fourth style, and a local decorative language began to develop in the north that partly distanced itself from the other. In fact, the archaeological evidence does not show fanciful elaborations of architectural perspectives; rather, it proves a predilection for contrasting monochrome panels delimited by ornamental borders. These started to gain an ever-greater importance in the wall painting structure, as did also the narrow spaces inserted between the panels in the middle zone, the so-called inter-panels. Invaded by fanciful decoration, these panels mark the rhythm of the wall to create original compositions and a peculiar decorative imprint, destined to be very successful until at least the fourth century AD. This consists of using a flat two-dimensional compositional scheme in which the wall is divided into panels and interpanels painted in vivid contrasting colours and enlivened by vegetal and figurative elements, some of which are particularly refined. The most appreciated decorative motifs, especially in the central zone, include isolated human figures and vignettes, landscapes, fishponds and, in the inter-panels, which actually become now the real focus of the decoration, candelabra and varied vegetal ornaments (Salvadori and Didonè 2018; Barbet 2009).

A remarkable example of these comes from a house in Aquileia, identified in the area below the Christian basilica. The wall section reconstructed from the fragments found during the excavation consists of a yellow inter-panel with a 

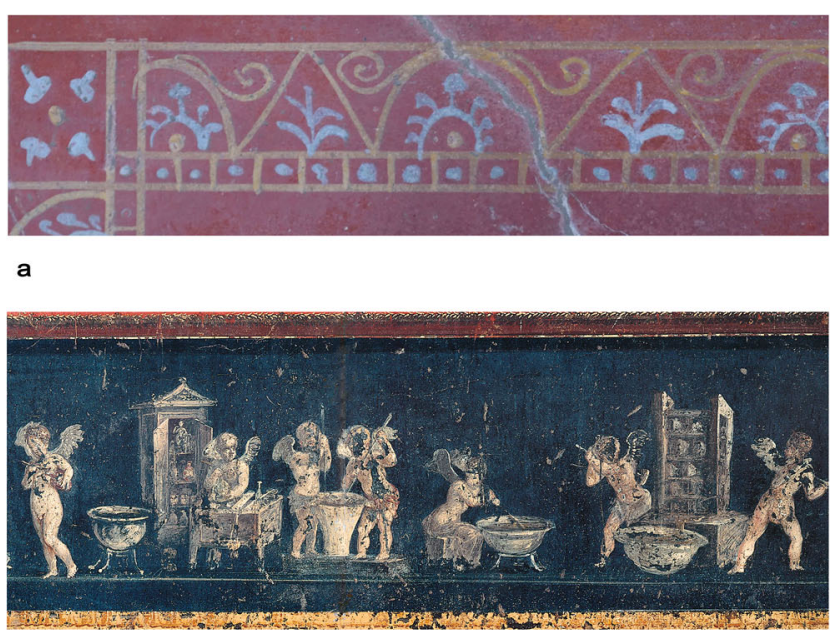

b

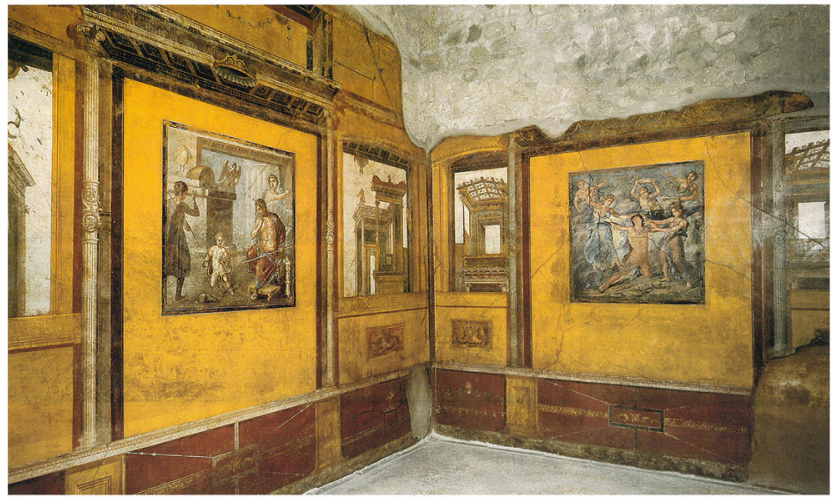

Fig. 13 a Embroidery border, Casa di M. Fabius Rufus (VII 16, 22), Pompeii (photo by author). b Predella with cupids making perfumes and psychai, Casa dei Vettii (VI 15, 1), Pompeii (Baldassarre et al. 2002 pp 232-233). c Heracles strangling snakes, Pentheus torn apart by maenads, Casa dei Vettii (VI 15, 1), Pompeii, southern triclinium (Mazzoleni et al. 2004, p 337)

silver-like candelabrum with a blue-white "umbrella" on top of which stand a pair of felines and a deer. The fragments discovered, some of which comprise portions of figurative scenes, suggest skilled painters worked in Aquileia in the second half of the first century AD.

\section{Figurative repertoire}

\section{Megalography}

The term megalography comes from Vitruvius (Vitr. arch. VII 5, 1-4) who, in describing the decorative trends of the so-called second style, mentions the presence of signorum megalographiam, i.e. "monumental paintings of figures" (Rouveret 2002). These near life-size representations are defined as megalographiae to indicate both the monumentality of the figures and the elevated subject matter.
The most famous example of megalography is undoubtedly that of the frieze of the tablinum (5) in the Villa dei Misteri in Pompeii. Twenty-nine characters belonging to Dionysus' entourage, both human and mythological, are participating in an initiation into the Dionysian Mysteries or in a wedding (Fig. 14a).

To the left of the doorway, a female figure wrapped in a purple and gold cloak, her head veiled, sits on a bench, her chin resting on her right hand while she is reflecting and watching the scene unfolding along all the walls of the room. Dionysus occupies the focal point of the eastern wall, in front of the main entrance to the room. The god is inebriated and reclining on the lap of a seated female figure. The other figures are represented in groups and "freeze" different moments of the sacred mythical-ritual and mythical-ecstatic ceremony. To the left of the divine couple (Dionysus-Semele/Ariadne/ Venus), an old Silenus, seated and holding a large tympanum (behind him), offers a silver cup to a young satyr who, looking into the cup, sees reflected the Silenian mask another young satyr is holding aloft.
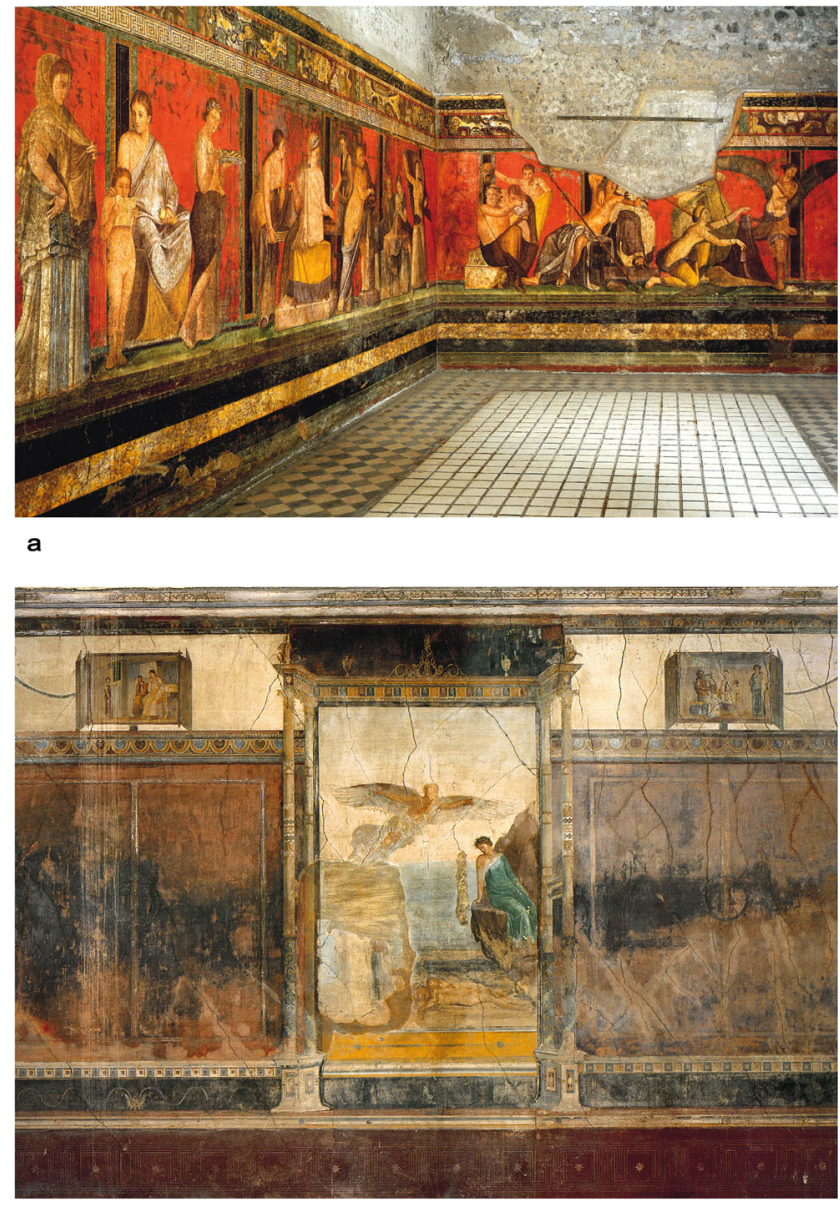

b

Fig. 14 a Megalographia with the mysteries of Dionysus, Villa dei Misteri, Pompeii, tablinum (5). b Fall of Icarus and pinakes, Villa Imperiale, Pompeii (Mazzoleni et al. 2004, pp 106, 243) 
On the right, a semi-kneeling woman is lifting a purple cloth to show the ritual object placed in the basket in front of her. Behind her, a young girl holds a tray with a bunch of pine needles, while another winged female figure, the upper part of her body naked, looks back and raises her right arm holding a rod, likely to whip the kneeling girl on the adjacent wall. This is probably a representation of the moment of the unveiling of the ritual phallus (a symbol of regeneration) during the celebration of the initiation rites.

On the adjoining southern wall, a girl kneels down, her back bare, the hair loose and the eyes closed, on the lap of a seated woman who holds and comforts her. The woman is dressed in white and her hair is gathered in a cap. On the right, a maenad portrayed in three-quarter view is dancing and playing cymbals (crotales); another female figure behind her wearing a long dress, her hair coiffed, is holding a thyrsus. On the opposite (northern) wall, a figure with a swollen mantle around her head looks back towards the old Silenus and raises her left hand in a gesture of revulsion at the scene she is observing. Next to her, two young satyrs are sitting on a rock, the man playing a syrinx and the panisca breastfeeding a roe deer. Behind them, an elder Silenus resting on a pillar is playing a lyre. Three female figures are celebrating a ritual around a table (lustratio), while a fourth one comes from the left carrying a tray with ritual cakes or flatbreads (a symbol of the fertility of the land that yields crops). Behind her a naked boy is reading a rotulo, a seating woman posing her right hand on his right shoulder while clutching a scroll in the other. Next to them, a standing matron in profile and wrapped in a cloak, her head veiled, is observing the ritual.

In the south-west corner, a female figure is seated on a stool combing her hair, assisted by a handmaiden (ornatrix) and two cupids: one holds up a mirror, while the other looks at her (Ling 1991).

The exegesis of the composition is particularly controversial, and interpretations are still not unanimous, chiefly due to both the theme being narrative and mythical/allegorical at a time and the intrinsic nature of Dionysian Mysteries, which were secret and accessible only to initiates. This is the reason why no literary sources document the initiation rites, allowing to identify the various moments of the ceremony.

There have been numerous interpretation attempts; the most widely accepted one understands the frieze as the initiation of a young female adept in the presence of deities and mythical characters. The girl, although still spiritually a child, undergoes trials to be re-born in the cult of the god. According to another reading, the frieze represents the wedding of a Roman aristocratic girl who is preparing to embrace her new status of bride and matron under the aegis of Dionysus (Ling 1991; Patanè 2003; Pappalardo 1982, 2013; Sauron 1998, 2009).

Another impressive megalography is depicted in the most important reception room of the Villa of $P$. Fannius Synistor in Boscoreale. The scenes take place on a red cinnabar background and are slightly larger than life-size.

Although the identification of the single figures is still debated, it is likely an allegorical commemoration of Alexander the Great's conquest of Asia and, more broadly, a celebration of the Macedonian dynasty.

Macedonia is portrayed as a female figure holding a spear and wearing a headdress with a tubular diadem, her shield featuring the famous Macedonian star. Another seated woman wearing oriental clothes, the personification of Asia, looks at her. Next to the two female figures is a half-naked old man wrapped in a cloak, whom his long beard and knobby walking stick suggest to identify with a philosopher (although his identity cannot be guessed). His presence is probably linked to the importance that such figures had at the Macedonian court.

On the opposite wall (now at the Metropolitan Museum of Art in New York), there are Alexander the Great's father, Philip II, and his mother Eurydice; a seated female figure identified as Olympias, Alexander's mother, playing the lyre and assisted by a handmaids; and a priestess reading the future that is reflecting in a mirror (the divinatory practice of katoptromanthía), who is prophesying Alexander's birth, whose image materialises on a golden shield (Smith 1994; Pappalardo 2013; Bragantini 2009; Bragantini and Sampaolo 2009, pp. 171-172, 178-179).

\section{Panel pictures}

Since the mid-first century BC, reproductions of paintings of various subjects were included in the wall decoration systems. The taste for painting panel pictures reflects the desire to imitate the apparatus of the most prestigious residences. The creation of private pinacothecae (pictures-galleries) and the parallel reproduction of illusionist galleries in wall paintings are instances of Roman luxuria, which spread from the late Republic, when, following the Roman conquest of Greece and the East, goods of all kinds and valuable objects and artworks came to Rome (Torelli et al. 2011).

Illusionist galleries of movable paintings with wooden frames or shutters (pinakes) hung on the wall or placed on shelves aimed at emulating great easel paintings (Fig. 14b). These fictious panel pictures could be of various sizes and represent views of ports or villas, idyllic-sacred landscapes with small temples populated by shepherds, wanderers or fishermen (Ling 1991; Salvadori 2008; La Rocca et al. 2009), as well as Nilotic landscapes with ibises and pygmies (Versluys 2002), still lives (Croisille 1965, 2015; De Caro 2001), genre scenes or scenes from everyday life (Clarke 2003; Tortorella 2009) and, above all, mythological themes (Lorenz 2008; Salvo 2018). The great mythological paintings selected one or more of the most significant episodes of a subject or saga indeed, in order for their representations to appear comprehensible and evocative to ancient observers. 
Each workshop had its own repertoire of models and sketches (Peters 1977), and different characters were depicted repeating the same iconographic schemes. The attributes of each character permitted the viewer to recognise the theme and the moment depicted (Salvo 2018, 2020). The Villa Imperiale's pseudo-paintings represent one of the most significant examples in Pompeii.

The third style paintings of the hall (a) (used as a reception room-oecus) largely survived to the devastating earthquake of $62 \mathrm{AD}$; instead, those in the upper zone and the vault collapsed along with the roof and were restored in the fourth style.

The middle zone of each wall consists of a series of red panels separated by thin columns; in the centre, a bidimensional aedicula frames a large mythological painting. In the upper zone, six small paintings with open and folded shutters (pinakes) depicting portraits of poets seem to rest on small supporting shelves like they were real.

All the mythological paintings in this sumptuous room refer to the Cretan world and are likely a reflection the dominus' desire for an extremely sophisticated and refined decorative apparatus. They include the unlucky flight of Icarus who, having ignored his father Daedalus' recommendation not to fly too close to the sun with his wax-soaked wings, now lies lifeless on the ground; Theseus killing the ferocious Minotaur and thus freeing the Athenian youths (whom the monstrous creature would have eaten) that are joyfully kissing the hero as a sign of gratitude; and Theseus' abandoning on the island of Naxos the Cretan princess Ariadne who is sleeping on the ground while the hero is ready to set sail for his homeland (Fig. 14b). The coherence of the mythological themes and their distribution in the room are evidence of a precise decorative programme aiming at imitating a private art collection (Pappalardo 1987, 1995, 2013; Mazzoleni et al. 2004; Romizzi 2006).

\section{Gardens}

The illusionist garden of the underground chamber of Livia's Villa ad gallinas albas near Prima Porta is one of the bestknown examples of Roman wall painting (Fig. 15a). It is the earliest known example of a painting genre that appeared in Rome in the last decades of the first century BC and whose introduction is believed to be due to imperial patronage.

What was the function of this large underground room of Livia's estate (whether a cool place to rest in summer, a meeting place connected to the baths nearby, or a nymphaeum) is still debated (Mazzoleni et al. 2004; Sauron 2009). Here, on the day of her wedding with Augustus, Livia was the protagonist of a prodigious event. Tradition has it that an eagle clutching a white hen dropped it into Livia's lap. The hen was holding a laurel branch in its beak. Livia planted the twig, creating a thick wood surrounding the villa that would

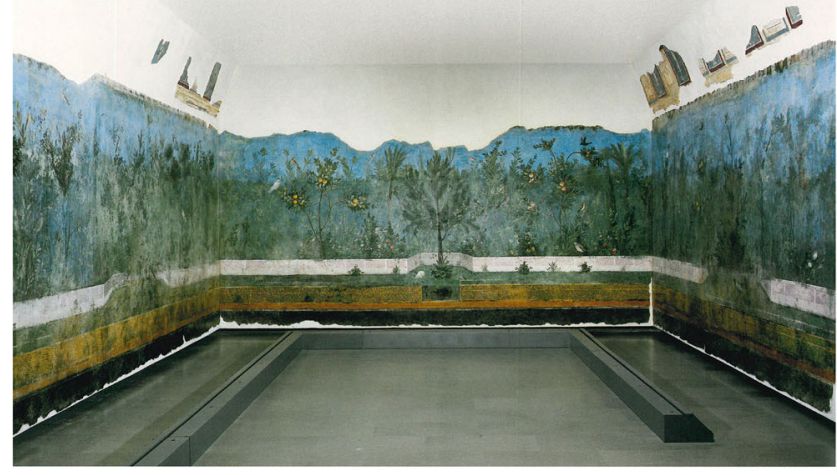

a

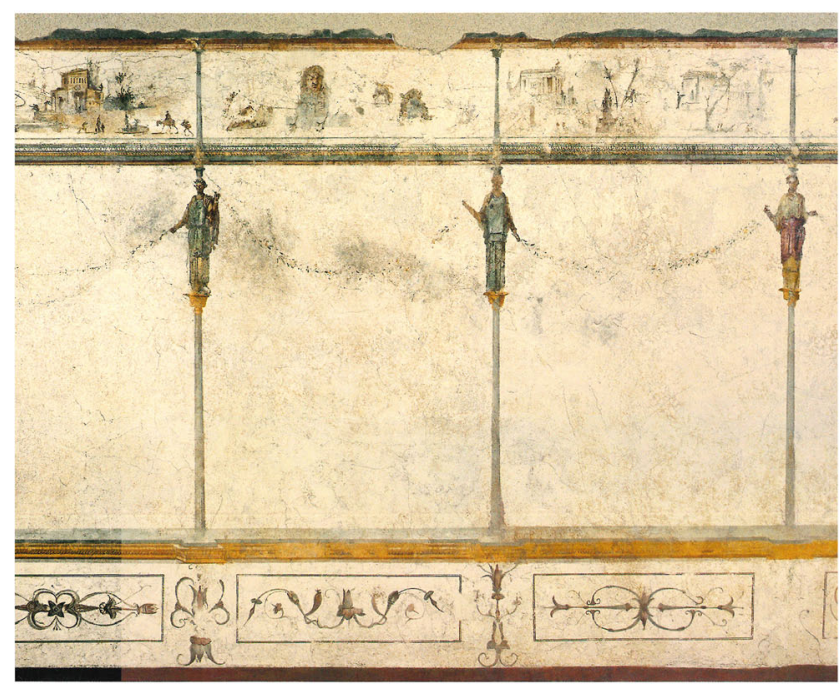

b

Fig. 15 a Painted garden, Villa di Livia ad gallinas albas (Rome, Museo Nazionale Romano, Palazzo Massimo alle Terme). b Landscapes, Villa della Farnesina, cryptoporticus (f) (Rome, Museo Nazionale Romano, Palazzo Massimo alle Terme) (Mazzoleni et al. 2004, pp 191, 212)

provide the wreaths for the triumphs of the Caesars to come. The decorative system dates likely around $20 \mathrm{BE}$; its chronology is controversial though, as due to the high quality level of the paintings, it is difficult to compare them with any other artisanal work. The decoration covers all the four walls of the room completely, and it is interrupted only in the centre of the eastern wall by the entrance.

Along the baseboard, two fences run parallel to one another. The one that looks closer to the viewer is yellow and thick, while the farther one is a marble balustrade; it is decorated with various serial motifs in relief (imitating trellises, gates, and "scales pattern") and has six quadrangular niches, two in each of the long sides and one in the short ones. All the niches on the long sides stage four fir trees while those on the short sides feature a pine and an oak. In correspondence with the short sides' niches, the first fence has two openings that reveal a narrow ambulatio. A lush garden full of numerous flowering plants, shrubs and trees is visible beyond the balustrade 
that supports a birdcage. The vegetation includes oleanders, pomegranates, laurel, apples, palms, strawberries, myrtles, viburnum and box trees as well as roses, poppies, white and yellow daisies and acanthus plants. Numerous birds are perched on the trees, while others fly high in the blue sky along the upper band. This is crowned by a series of light brown motifs that have been variously interpreted by scholars as stalactites or leaves of a bower or a garland (Settis 2008; Salvadori 2017). The decoration of the barrel vault consisted of stucco lacunars with winged Victories that were only partially preserved when this room was discovered in 1863. In 1951-1952, the paintings were detached and transported to the Museo Nazionale Romano; the detachment laid bare a layer of tiles that had been applied underneath the plaster to form a cavity that would insulate the paintings from moisture.

More than a hundred years after the discovery of the garden paintings in the Villa of Livia, archaeologists are still debating over whether, given the exceptional conception and formal execution of these frescoes, they should be regarded as the product of an inventio inspired by Livia and the miraculous event she had been the protagonist of, or, rather, as a particularly refined and successful instantiation of a pre-existing genre.

Whatever the case, this representation seems to have influenced the genre of garden paintings, which appear in many other contexts for a long period, especially in the Vesuvian area. Among the numerous evidence, the example of the Casa del Bracciale d'oro in Pompeii (VI 17 Insula Occidentalis 42) is worth mentioning. This house is built on three levels on a slope surface and rests on the city walls. The lowest floor corresponds to the base of the walls and has two rooms built into the supporting arches of the upper floor; they open a garden with a fountain in the centre and a pergola all around. Both these rooms are completely covered by garden paintings. Room (31) is a triclinium with masonry beds and has also a niche at the end of the eastern wall which is decorated with polychrome mosaics reproducing a garden with fountains and birds. This and the garden paintings all around the other walls generate the illusion of being a real pergola pavillon. The lush garden stands against a blue sky and is adorned with artefacts of Egyptian inspiration (sphinxes, Pharaonic statues, paintings of the ox Apis) and fountains. There are oleanders and strawberry bushes, among which birds of various species fly. Room (32), interpreted as a cubiculum, features a fence with rectangular, cuspidate and rhomboidal hole. Above it, a garden full of oleanders, laurel, strawberry bushes, viburnum, roses and ivy, camomile plants, palm trees and plane trees stands against a blue sky. Amidst the vegetation, there are circular fountains pouring water and hermas supporting pinakes representing the sleeping Ariadne and a Maenad. Pigeons, swallows, sparrows, magpies and an oriole are perched on branches or fly, while two female tragic masks are hung up on the upper part of the wall.

The quality of these frescoes is outstanding and has been compared to two other examples documented in the Casa dei cubicoli floreali (I 9, 5-7); someone has argued that the same artists might have worked in both the Pompeian houses in the first decades of the first century AD (Moormann 1995b).

More recent is the large porticoed garden of the Casa della Venere in conchiglia (II 3,3), dating to the last phase of Pompeii's life. This example is of particular relevance due to the association of the garden painting with a mythological image. The wall visible in front the atrium is divided into three parts by large arches that look like imaginary windows. The larger arch in the centre frames the birth of Venus; the goddess is lying on a shell, flanked by two cupids. The two side arches instead enclose two gardens on a blue background. The eastern one features a marble statue of Mars on the central pedestal, while the western one hosts a circular fountain pouring water. The iconographic motif of the garden, which is iterated along all the other walls delimiting the house's real garden, is further enriched here as it develops under the protection and control of the goddess Venus, whose area of action is traditionally related to this space.

\section{Landscapes}

As already discussed, that of the landscape is a pictorial genre well documented from the Augustan age onwards. Vitruvius himself, when describing wall painting decorations, explicitly mentions landscapes (Vitr. arch. VII 5, 1-2). He refers to a variety of places (topia): ports, promontories, beaches, rivers, springs, sea straits, sanctuaries, sacred woods, mountains, flocks and shepherds. The list of topia and the reference to their "collective" character recur also in Pliny's Naturalis Historia (XXXV, 116 à XXXV, 37, 116). Pliny's passage on landscape painting not only broadens the types of places and the actions of the people therein, but it also adds further information. He contends that the landscape genre was invented by one Studius, who lived in the Augustan age and who achieved a high reputation with works of beautiful aspect but low cost. There is no doubt that the painter referred to by Pliny - one of the few names of Roman artists handed down to us - earned his reputation; his style was likely based on an established repertoire, with reference to which he created typified and fantastic images.

In the above-mentioned complex of the Villa della Farnesina, landscape paintings on white backgrounds appear not only in the triclinium, but also in the cryptoporticus, where also the stuccoes on the vault reproduce landscape views. Along the upper part of the walls, landscape paintings alternate with enigmatic still lives comprising masks - an iterative decoration typical of transit spaces. The landscapes, rendered in simple tones of green and ochre ranging from brown to 
yellow, reveal a remarkable creativity in the choice and combination of the elements (Fig. 15b). Alongside the genre paintings, portraying both rural and maritime panoramas, they open views to real landscapes, such as the Isthmus of Corinth, characterised by Lysippus' statue of Poseidon.

Particularly successful at the beginning of the imperial age were the sacred landscapes; very famous are those depicted in grey on a white background enclosed in the central aediculae of the so-called mask room in the House of Augustus on the Palatine. The meaning of these landscapes paintings - which do not look like "beyond spaces"-is enriched of a symbolic value due to the presence of the typical attributes of Augustus's protective deities, including the betyle, the aniconic symbol of Apollo (Salvadori 2008).

\section{Concluding remarks and future perspectives}

At the end of this overview of Roman wall painting's techniques and stylistic and iconographic evolution from the Republic to the Early Empire, it is worth underlying that researches in this field as relates to the provinces of the Roman Empire began only after the mid-twentieth century, whereas studies in wall painting in the Vesuvian area have bourgeoned since the nineteenth to the present day without pause. As far as non-Vesuvian wall painting is concerned, the pioneering work of W. Drack on the corpus of fragmentary paintings from Switzerland is worth mentioning. His Die römische Wandmalerei der Schweiz was published in 1950; it provides a rigorous analysis of the wall paintings that had been brought to light in the first half of the twentieth century, integrating descriptions of the decorations with information on the archaeological context and stylistic analyses chiefly based on comparisons with the closest evidence in the area (and therefore not only with Roman and Campanian documentationDrack 1950; Fuchs and Dubois 2018). As it has been recently underlined (Barbet 2018), Drack's work represents a milestone in Roman provincial wall painting studies, and its approach was innovative in that it stressed the relevance of interpreting wall decorations in connection to their architectural context. Moreover, Drack documents his tentative reconstructions of any decoration system (or portions thereof) from its fragments with accurate graphic and photographic documentation. Drack's "global" approach to the study of Roman wall painting in Switzerland is more original than S. Aurigemma's corpus of Tripolitania (Northern Africa) paintings, published about a decade later and yet very valuable (Aurigemma 1962). The corpus, illustrated by a remarkable number of colour images and graphic reconstructions of the paintings, focuses on the analysis of individual iconographic elements but loses sight of a comprehensive insight into the phenomenon of wall painting.
A step forward into the study of Roman provincial wall painting was Alix Barbet's 1975 monograph on the paintings of Glanum (Southern France), which was supposed to be the first of a series of volumes dedicated to wall painting in Gaul (Barbet 1975). Although this project has later been abandoned in favour of a series of publications focusing on single contexts, it is worth noting that not only did Barbet's volume mark the birth of prolific French-speaking researches in Roman provincial wall painting, but also a method of investigation that would drive any subsequent study with regard to the analysis of the tectorium - its anchoring to the masonry, the compositional characteristics of the layers, the execution of the preparatory drawings on the paint film, the composition of the pigments and the presence of binders.

This new approach revitalised the studies in Roman painting, leading to an increase in the number of publications in the following decades (e.g. Abdal Casal 1982 for Spain) It impacted also on the centennial studies in Roman wall paintings in the Vesuvian area, which began to focus on the production process and to understand it as artisanal manufacturing only from the 1990s onwards.

Broadening the perspective, in the last 20 years of the twentieth century, they established the "Association française pour la peinture murale antique" (AFPMA, in 1979) and the "Association internationale pour la peinture murale antique" (AIPMA, officially established in Köln in 1989 after three conferences held in Cambridge in 1980, in Paris in 1982 and in Avenches 1986), followed, in 2016, by the "Associazione italiana ricerche pittura antica" (AIRPA).

These associations are fertile grounds for updating and critical discussion at national and international level and might pave the way for Roman wall painting to be investigated from a holistic, global and polycentric perspective.

In the future, it would be desirable to put in practice a more constant integration between humanistic and scientific skills that can lead to an accurate diachronic definition of ancient painting styles and techniques.

For example, the number of archaeometric studies currently available for the Vesuvian area is still very small, both on mortars (see, e.g. Castriota et al. 2008; Izzo et al. 2016; Leone et al. 2016; Rispoli et al. 2019), and on pigments (see, e.g. Duran et al. 2010; Casoli and Santoro 2012; Castellini et al. 2019). Studies unrelated to the evidence of a single site are often focused on degradation issues (Grifa et al. 2016; Merello et al. 2016), while there is a lack of studies aimed at characterising specific styles.

Even outside the Vesuvian area, the archaeometric investigations on ancient wall paintings are often oriented to the study of single sites (e.g., Hernanz et al. 2008; Gutman et al. 2016; Guirdzhiiska et al. 2017), and the reference to defined styles is not always evident.

As a further example, among the various examples cited in the previous pages, archaeometric studies are often absent. 
On the other hand, the recent research carried out by Cuní (2016) on painting techniques in Roman wall paintings has shown how archaeometric analyses may cast doubt on some reconstructions on painting media. Similarly, studies on mortars and plasters have often found that the "standard" preparation handed down from ancient resources was often simplified or modified.

Therefore, an increase in research and an expansion of results that integrate historical, historical-artistic, archaeological and archaeometric data is needed to validate current knowledge and establish meaningful parallels between information deduced from ancient resources, historical-artistic studies, archaeological evidence and archaeometric investigations.

Supplementary Information The online version contains supplementary material available at https://doi.org/10.1007/s12520-021-01411-3.

Funding Open access funding provided by Università degli Studi di Padova within the CRUI-CARE Agreement.

Author contribution Monica Salvadori: Introduction; Ancient sources; Decorative schemes; The styles of Roman painting and Mau's theory; First style ("incrustation") and its antecedents: masonry style, "zero" style; Second style ("architectural-illusionistic"); Third style ("ornamental"); Fourth style ("intricate"); Gardens; Landscapes; and Conclusions

Clelia Sbrolli: Introduction; Preparation techniques; Characteristics of tectorium and preparatory layers of mortar; Plaster anchoring systems; Sketches, outline incisions and corda battuta (chalk-line); Painting techniques; Affresco, mezzo-fresco, a secco, surface treatment and finishing; Pontate ("scaffoldings")/giornate ("working days"); Megalography; and Panel pictures

Declarations The authors have no conflict of interest to declare.

Data sharing is not applicable to this article as no new data were created or analysed in this study.

Open Access This article is licensed under a Creative Commons Attribution 4.0 International License, which permits use, sharing, adaptation, distribution and reproduction in any medium or format, as long as you give appropriate credit to the original author(s) and the source, provide a link to the Creative Commons licence, and indicate if changes were made. The images or other third party material in this article are included in the article's Creative Commons licence, unless indicated otherwise in a credit line to the material. If material is not included in the article's Creative Commons licence and your intended use is not permitted by statutory regulation or exceeds the permitted use, you will need to obtain permission directly from the copyright holder. To view a copy of this licence, visit http://creativecommons.org/licenses/by/4.0/.

\section{References}

Abad Casal L (1982) Aspectos técnicos de la pintura mural romana en España. Lucentum I 52

Abdal Casal L (1982) La pintura mural romana en España, Sevilla

Aceto M (2021) The palette of organic colourants in wall paintings. Archaeological and Anthropological Sciences. https://doi.org/10. 1007/s12520-021-01392-3

Adam J-P (1988) L'arte di costruire presso i romani, materiali e tecniche, Milano
Aliatis I, Bersani D, Campani E, Casoli A, Lottici PP, Mantovan S, Marino IG (2010) Pigments used in Roman wall paintings in the Vesuvian area. J Raman Spectrosc 41(11):1537-1542

Allison P (1995) "Painter-workshops" or “decorators' teams"? In: Moormann EM (ed) (1995a) pp 61-298

Arizzi A, Cultrone G (2021) Mortars and plasters - how to characterise hydraulic mortars. Archaeological and Anthropological Sciences. https://doi.org/10.1007/s12520-021-01404-2

Aurigemma S (1962) L'Italia in Africa. Le scoperte (1911-1943). In: Tripolitania I. Le pitture d'età romana, Roma

Baggio M, Salvadori M (2017) Tessuti, velari e tende nella pittura parietale antica: alcune riflessioni. In: Vidale M, Angelini A (eds) Cupitò M. Beyond Limits. Studi in onore di Giovanni Leonardi, Firenze, pp 209-217

Baldassarre I (2002) la Domus Aurea. In: Baldassarre et al. 2002, pp 216-225

Baldassarre I, Pontrandolfo A, Rouveret A, Salvadori M (2002) Dall'ellenismo al tardo antico, Milano

Barbet A (1975) Recueil général des peintures murales de la Gaule, I, Narbonnaise, 1, Glanum. XXVII Supplément à Gallia, Paris

Barbet A (1981) Les bordures ajourées dans le IVe style de Pompéi. Essai de typologie. Mélanges de l'Ecole française de Rome Antiquité 93:917-998

Barbet A (1985) (2009) La peinture murale romaine. Les styles décoratifs pompéiens, Paris

Barbet A (1998) La tecnica pittorica. In: Donati 1998, pp 103-110

Barbet A (2000) La pittura romana. Dal pictor al restauratore, Imola

Barbet A (2008) La peinture murale en Gaule romaine, Paris

Barbet A (2009) La peinture murale romaine. Les styles décoratifs pompéiens. Paris

Barbet A (2016) Recomposition et restitution des peintures murales fragmentaires : méthodologie, principes scientifiques et éthiques. Revue archéologique 2016/2 62:361-381

Barbet A (2018) Un demi-siècle de recherches sur la peinture murale antique. In Dubois Y, Niffeler U (eds) (2018) Pictores per provincias, II, 11-23

Barbet A, Allag C (1972) Techniques de préparation des parois dans la peinture murale romaine. Mélanges de l'Ecole française de Rome Antiquité 84-2:935-1070

Barbet A, Allag C (2000) La pittura romana: dal pictor al restauratore. Catalogo della Mostra, Trento, Palazzo Thun, giugno-settembre 2000-Bologna, Complesso di San Giovanni in Monte, ottobre 2000. Imola

Bastet FL, De Vos M (1979) Proposta per una classificazione del terzo stile pompeiano, Roma

Béarat H, Fuchs M, Maggetti M, Paunier D (eds) (1997) Roman wall painting: materials, techniques, analysis and conservation. Fribourg

Becker H (in press) Commerce in color: the mechanics of the Roman trade

Becker H (2021) Pigment nomenclature in the ancient Near East, Greece, and Rome. Archaeological and Anthropological Sciences. https:// doi.org/10.1007/s12520-021-01394-1

Beyen HG (1960) Die Pompeianische Wanddekoration vom Zweiten Bis zum Vierten Stil, voll. II-II, Haag

Bezerra de Meneses U (1970) Le revêtement mural. In: L'îlot de la Maison des Comédiens, Exploration archéologique de Dèlos XXVII, pp 151-193

Bianchi B (2009) "Ma in verità non c'è gloria se non per gli artisti che dipinsero quadri..." (Plinio il Vecchio, Naturalis Historia 35, 118). In: La Rocca E, Ensoli S, Tortorella S, Papini M (eds) (2009), pp 137-147

Bianchi B (2014) La decorazione pittorica del santuario repubblicano di Brescia. In: Rossi F (ed) Un luogo per gli dei. L'area del Capitolium a Brescia, Firenze, pp 223-259 
Borgard P, Brun JP, Leguilloux M, Truffea-Libre M (2003) Le produzioni artigiani a Pompei. Ricerche condotte dal Centre Jean Bérard RStPomp 14:9-30

Bragantini I (1990) Casa del Criptoportico e Casa del Sacello Iliaco. In: PPM I

Bragantini I (2004) Una pittura senza maestri: la produzione della pittura parietale romana. JRS 17:131-145

Bragantini I (2009) La villa di Boscoreale. In: Bragantini I, Sampaolo V (eds), pp 40-42

Bragantini I (2014) La pittura a Pompei nell'opera di August Mau, Geschichte der decorativen Wandmalerei in Pompeji (Berlin 1882): note di lettura. In: Eristov H, Monier F (eds) L'héritage germanique dans l'approche du décor antique, vol 2. Pictor, pp 9-18

Bragantini I (2019) Towards a cultural biography of Roman painting. JRA 32:129-147

Bragantini I, Sampaolo V (eds) (2009) La Pittura Pompeiana, Milano

Brecoulaki H (2006) La peinture funéraire de Macédoine: Emplois et fonctions de la couleur IVe-IIe siècle avant J-C. Athènes

Brun JP (2008) Uno stile zero? Andron e decorazione pittorica anteriore al primo stile nell'insula I 5 di Pompei. In: Guzzo PG, Guidobaldi MP (eds) Nuove ricerche archeologiche nell'area vesuviana (scavi 2003-2006). Atti del Convegno internazionale, Roma, pp 61-70

Bruno VJ (1969) Antecedents of the Pompeian First Style. AJA $73: 305-317$

Burgio L (2021) Pigments, dyes and inks - their analysis on manuscripts, scrolls and papyri. Archaeological and Anthropological Sciences. https://doi.org/10.1007/s12520-021-01403-3

Caminneci V, Lepore G (eds) (2019) I colori di Agrigentum. Catalogo della Mostra, Agrigento, Museo Archeologico Regionale P. Griffo, 1 dicembre 2019 - 8 marzo 2020. Agrigento

Capus P, Dardenay A (eds) (2014) L'Empire de la Couleur, de Pompéi au sud des Gaules. Catalogue de l'exposition (Toulouse, Musée SaintRaymondfig. 15 novembre 2014 - 22 mars 2015) Toulouse, p 111

Carrive M (2017) Remployer, recycler, restaurer : les autres vies des enduits peints, École française de Rome. Collection de l'École française de Rome 540, Rome

Caroselli M, Ruffolo SA. Piqué F (2021) Mortars and plasters - how to manage mortars and plasters conservation. Archaeological and Anthropological Sciences. https://doi.org/10.1007/s12520-02101409-x

Casoli A, Santoro S (2012) Organic materials in the wall paintings in Pompei: a case study of Insula del Centenario. Chemistry Central Journal 6(1):107. https://doi.org/10.1186/1752-153X-6-107

Castellini P, Martarelli M, Lenci S, Quagliarini E, Silani M, Martellone A (2019) Diagnostic survey on frescoes paintings in Pompei by active Ir-thermography. IMEKO International Conference on Metrology for Archaeology and Cultural Heritage, MetroArchaeo 2017 (lecce, Italy 23-25 October 2017). 51-56

Castriota M, Cosco V, Barone T, De Santo G, Carafa P, Cazzanelli E (2008) Micro-Raman characterizations of Pompei's mortars. J Raman Spectrosc 39(2):295-301. https://doi.org/10.1002/jrs.1877

Cavallo G, Riccardi MP (2021) Glass-based pigments in painting. Archaeological and Anthropological Sciences. (forthcoming)

Clarke JR (2003) Art in the lives of ordinary Romans. Visual representation and non-elite viewers in Italy, 100 B.C. - A.D. 315. BerkeleyLos Angeles

Croisille JM (1965) Les natures mortes campaniennes. Répertoire descriptif des peintures de nature morte du Musée National de Naples, de Pompéi, Herculanum et Stabies. Bruxelles

Croisille JM (2015) Natures mortes dans la Rome antique. Naissance d'un genre artistique, Paris

Cuní J (2016) What do we know of Roman wall painting technique? Potential confounding factors in ancient paint media analysis. Heritage Science 4(1):44. https://doi.org/10.1186/s40494-0160111-4
Daniele D, Gratziu C (1996) Marmo e calcite spatica di vena: termine di un equivoco sull'intonaco vitruviano. Annali della Scuola Normale Superiore di Pisa, s IV 21:541-548

De Caro S (2001) La natura morta nelle pitture e nei mosaici delle città vesuviane, Napoli

DeLaine J (2021) Production, transport and on-site organisation of Roman mortars and plasters. Archaeological and Anthropological Sciences. https://doi.org/10.1007/s12520-021-01401-5

De Miro E (1966) Heraclea Minoa. Risultati archeologici e storici dei primi scavi sistematici nell'area dell'abitato. Kokalos 12: 221-233

Dilaria S, Sbrolli C (2018) I frammenti di intonaco dipinto. In: Basso P (ed) L'Anfiteatro di Aquileia - Ricerche d'archivio e nuove indagini di scavo. Scavi di Aquileia V, Mantova, pp 151-158

Domingo Sanz I, Chieli A (2021) Characterising the pigments and paints of prehistoric artists. Archaeological and Anthropological Sciences. https://doi.org/10.1007/s12520-021-01397-y

Donati A (ed) (1998) Romana Pictura. La pittura romana dalle origini all'età bizantina, Catalogo della Mostra (Rimini, Palazzi del Podestà e dell'Arengo 28 marzo - 30 agosto 1998). Venezia

Drack W (1950) Die Römische Wandmalerei der Schweiz, Basel

Dubois Y, Niffeler U (eds) (2018) Pictores per provincias, II. Status quaestionis, Actes du $13^{\mathrm{e}}$ colloque de l'Association Internationale pour la Peinture Murale Antique (AIPMA), (Lausanne, 12-16 septembre). Antiqua 55. Basel

Duran A, Jimenez De Haro MC, Perez-Rodriguez JL, Franquelo ML, Herrera LK, Justo A (2010) Determination of pigments and binders in Pompeian Wall paintings using synchrotron radiation - high-resolution X-Ray powder diffraction and conventional spectroscopy chromatography. Archaeometry 52(2):286-307. https://doi.org/10. 1111/j.1475-4754.2009.00478.x

Ergenç D, Fort R, Varas-Muriel MJ, Alvarez de Buergo M (2021) Mortars and plasters - how to characterise aerial mortars and plasters. Archaeological and Anthropological Sciences. https://doi.org/ 10.1007/s12520-021-01398-x

Eristov H (1987) Peinture romaine et textes antiques. Informations et ambiguïtés À propos du Recueil Milliet Revue archéologique $1: 113-123$

Esposito D (1999) La bottega dei Vettii: vecchi dati e nuove acquisizioni. RStPomp 10

Esposito D (2007) I pittori dell'officina dei Vettii a Pompei. Meccanismi di produzione della pittura parietale romana BABesch 82:149-174

Esposito D (2009) Le officine pittoriche di IV stile a Pompei. Dinamiche produttive ed economico-sociali. Studi della Soprintendenza Archeologica di Pompei 28, Roma

Esposito D (2011) Il sistema economico e produttivo della pittura romana. Esempi dall'area vesuviana. In: Monteix N, Tran N (éds) Les savoirs professionnels des gens de métier. Études sur le monde du travail dans les sociétés urbaines de l'empire romain. Collection du Centre Jean Bérard 37. Napoli, pp 65-85

Esposito D (2016a) Il lavoro degli anonimi. Lo status quaestionis delle ricerche sull'operato dei pittori romani Babesch 91:173-195

Esposito D (2016b) The Economics of Pompeian Painting. In: Wilson A, Flohr M. (eds) The Economy of Pompeii, Oxford, pp 263-289

Esposito F, Falcucci C, Ferrara D (2011) La tecnica esecutiva dei dipinti del Salone 5 della Villa dei Misteri: Cento anni di ipotesi e ricerche. Rivista Di Studi Pompeiani 22:149-158

Falzone S (2007) Ornata aedificia. Pitture parietali dalle case ostiensi, Roma

Flohr M (2019) Artisans and markets: the economics of Roman Domestic Decoration. AJA 123, 1, January 2019:101-112

Fuchs M, Dubois Y (2018) Avant-propos. In: Dubois Y, Niffeler U (eds) (2018) Pictores per provincias, II, pp 9-10

Gliozzo E, Burgio L (2021) Pigments - Arsenic-based yellows and reds. Archaeological and Anthropological Sciences. https://doi.org/10. 1007/s12520-021-01431-z 
Gliozzo E, Ionescu C (2021) Pigments - Lead-based whites, reds, yellows and oranges and their alteration phases. rchaeological and Anthropological Sciences. https://doi.org/10.1007/s12520-02101431-Z

Gliozzo E (2021) Pigments - Mercury-based red (cinnabar-vermilion) and white (calomel) and their degradation products. Archaeological and Anthropological Sciences. https://doi.org/10. 1007/s12520-021-01402-4

Gliozzo E, Pizzo A, La Russa MF (2021) Mortars, plasters and pigments research questions and sampling criteria. Archaeological and Anthropological Sciences. https://doi.org/10.1007/s12520-02101393-2

Grifa C, Barba S, Fiorillo F, Germinario C, Izzo F, Musmeci D, Pontrandolfo A, Santoriello A, Toro P, Langella A (2016) The Domus of Octavius Quartio in Pompeii: damage diagnosis of the masonries and frescoed surfaces. International Journal of Conservation Science 7(Specialissue2):885-900

Griffo MG (2008) Nuovi dati sull'edilizia di Lilibeo. In: Spanò Giammellaro A Caruso E (eds) Lilibeo e il suo territorio, Palermo, pp 93-101

Groetembril S (2016) Les peintures murales gallo-romaines. Le long chemin de la fouille à la restauration. In: Capus and Dardenay (2014), 114-118

Guidobaldi MP, Esposito D (2012) Ercolano. Colori da una città sepolta, Verona

Guirdzhiiska D, Zlateva B, Glavcheva Z (2017) Polished decorative fields in Thracian fresco tombs from the Hellenistic period archaeometrical research. Science and Technology of Archaeological Research 3(2):428-436. https://doi.org/10.1080/ 20548923.2017.1396723

Guldager Bilde P (1993) The international style. Aspects of Pompeian first style and its eastern equivalents. Acta Hyperborea 5:151-177

Gutman M, Zanier K, Lux J, Kramar S (2016) Pigment analysis of roman wall paintings from two villae rusticae in Slovenia. Mediter Archaeol Archaeom 16(3):193-206. https://doi.org/10.5281/ zenodo. 160970

Hernanz A, Bratu I, Marutoiu OF, Marutoiu C, Gavira-Vallejo JM, Edwards HGM (2008) Micro-Raman spectroscopic investigation of external wall paintings from St. Dumitru's Church, Suceava Romania. Anal Bioanal Chem 392(1-2):263-268. https://doi.org/ 10.1007/s00216-008-2262-y

Hinks RP (1933) Catalogue of the Greek, Etruscan and Roman paintings and mosaics in the British Museum, London

Iacopi I (2007) La casa di augusto. Le pitture. Roma

Izzo F, Arizzi A, Cappelletti P, Cultrone G, De Bonis A, Germinario C, Graziano SF, Grifa C, Guarino V, Mercurio M, Morra V, Langella A (2016) The art of building in the Roman period (89 B.C. - 79 A.D.): mortars, plasters and mosaic floors from ancient Stabiae (Naples, Italy). Constr Build Mater 117:129-143. https://doi.org/10.1016/j. conbuildmat.2016.04.101

Knapp CW, Christidis GE, Venieri D, Gounaki I, Gibney-Vamvakari J, Stillings M, Photos-Jones E (2021) The ecology and bioactivity of some Greco-Roman medicinal minerals: the case of Melos earth pigments. Archaeological and Anthropological Sciences. https:// doi.org/10.1007/s12520-021-01396-z

Lancaster LC (2021) Mortars and plasters - how mortars were made. The Literary Sources. Archaeological and Anthropological Sciences. https://doi.org/10.1007/s12520-021-01395-0

La Rocca E (2004) Lo spazio negato. La pittura di paesaggio nella cultura artistica greca e romana, Milano

La Rocca E, Ensoli S, Tortorella S, Papini M (eds) (2009) Roma. La pittura di un impero. Catalogo della mostra (Roma, Scuderie del Quirinale, 27 settembre 2009 - 17 gennaio 2010). Roma

La Russa MF, Ruffolo SA (2021) Mortars and plasters - how to characterise mortars and plasters degradation. Archaeological and
Anthropological Sciences. https://doi.org/10.1007/s12520-02101405-1

La Torre GF (2011) Origine e sviluppo dei sistemi di decorazione parietale della Sicilia ellenistica. In: La Torre GF, Torelli M (eds) Pittura ellenistica in Italia e in Sicilia. Linguaggi e tradizioni, Atti del Convegno di Studi (Messina 24-25 settembre 2009), Roma, pp 255-278

Lehmann PHW (1969) Samothrace III: the Hieron. Princeton

Lenzi S (2016) La policromia dei monochromata. La ricerca del colore su dipinti su lastre di marmo di età romana, Firenze

Leone G, De Vita A, Magnani A, Rossi C (2016) Characterization of archaeological mortars from Herculaneum. Thermochim Acta 624: 86-94. https://doi.org/10.1016/j.tca.2015.12.003

Ling R (1991) Roman Painting, Cambridge

Ling R (1999) Stuccowork and painting in Roman Italy. Ashgate, Aldershot

Lorenz K (2008) Bilder machen Räume, Berlin

Maiuri A (1938) Note su di un nuovo dipinto ercolanese. Bollettino d'Arte:481-489

Maiuri A (1940) Picturae ligneis formis inclusae: note sulla tecnica della pittura Campana, Roma

Malgieri A (2013) La bottega delle immagini parietali $\mathrm{I}^{\circ}$ sec. a. C.- $\mathrm{I}^{\circ} \mathrm{sec}$ d.C. Roma

Marin MD (1964) Scavi archeologici nella contrada S. Vito presso il lago di Salpi. In: Archivio Storico Pugliese 17:167-224

Mastrotheodoros GP, Beltsios KG, Bassiakos Y (2021) Pigments - ironbased red, yellow and brown ochres. Archaeological and Anthropological Sciences (forthcoming)

Mau A (1882) Geschichte Der Decorativen Wandmalerei In Pompeji, Berlin

Mazzoleni D, Pappalardo U, Romano L (2004) Domus. Pittura e architettura d'illusione nella casa romana, Milano

Merello P, Beltrán P, García-Diego F-J (2016) Quantitative non-invasive method for damage evaluation in frescoes: Ariadne's house (Pompeii, Italy). Environ Earth Sci 75(2):165. https://doi.org/10. 1007/s12665-015-5066-3

Meyboom PGP, Moormann EM (2013) Le decorazioni dipinte e marmoree della Domus Aurea di Nerone a Roma, Leuven

Mols STAMM (2005) Il Primo Stile "retró": dai Propilei di Mnesicle a Pompei. In: Mols STAMM, Moorman EM (eds) Omni pede stare. Saggi in Memoriam J. A. de Waele. Studi della Soprintendenza Archeologica di Pompei 9, Naple, pp 243-246

Moormann EM (ed) (1995a) Mani di Pittori e botteghe pittoriche nel mondo romano: tavola rotonda in onore di W.J. Th. Peteres in occasione del suo 75.mo compleanno (Dutch School, Rome, 1617 Maggio 1994). MededRom 54. Roma

Moormann EM (1995b) Giardini ed altre pitture nella Casa del frutteto e nella Casa del bracciale d'oro. In: Moormann EM (ed) (1995a), pp 214-227

Mora PL, Philippot P (1999) La conservazione delle pitture murali, Bologna

Mulliez M (2014) Le luxe de l'imitation. Les trompe-l'œil de la fin de la République romaine, mémoire des artisans de la couleur. Naples

Murat Z (2021) Wall paintings through the ages. The medieval period (Italy, $12^{\text {th }}-15^{\text {th }}$ century). Archaeological and Anthropological Sciences. https://doi.org/10.1007/s12520-021-01410-4

Pappalardo U (1982) Nuove osservazioni sul fregio della Villa dei Misteri a Pompei. La regione sotterrata dal Vesuvio. Studi e prospettive, Napoli, pp 599-634

Pappalardo U (1987) La "Villa Imperiale" a Pompei: rapporto preliminare. Dialoghi di Archeologia 2(1987):125-134

Pappalardo U (1995) La bottega della Villa Imperiale a Pompei. In: Moormann EM (ed) (1995a), pp 177-190

Pappalardo U (2013) Affreschi romani, Verona

Patanè S (2003) La villa degli Istacidii, detta anche dei misteri in Pompei, GRT004, Sarno 
Pérez-Arantegui J (2021) Not only wall paintings - pigments for cosmetics. Archaeological and Anthropological Sciences. https://doi. org/10.1007/s12520-021-01399-w

Pesando F (1996) Autocelebrazione aristocratica e propaganda politica in ambiente privato : la casa del Fauno a Pompei. Cahiers du Centre Gustave Glots 7:189-228

Pesando F (2011) Case d'età medio-sannitica nella Regio VI di Pompei: periodizzazione degli interventi edilizi e decorativi. In: Torelli M, La Torre G F (eds) Pittura ellenistica in Italia e in Sicilia. Linguaggi e tradizioni, Roma, pp 425-435

Peters WJT (1977) La composizione delle pareti dipinte nella Casa dei Vettii a Pompei. MededRom 39:95-128

Peters WJTh (1982) La composizione delle pitture parietali di IV stile a Roma e in Campania. In: La Regione sotterrata dal Vesuvio. Studi e Prospettive (Atti del Convegno internazionale 11-15 novembre 1979). Napoli, pp 635-659

Peters WJT (1993) La casa di Marcus Lucretius Fronto a Pompei e le sue pitture. L'Antiquité Classique 65:576-577

Piovesan R, Mazzoli C, Maritan L (2012) Fresco and lime-paint: an experimental study and objective criteria for distinguishing between these painting techniques. Archaeometry 54(4):723-736

Plisecka A (2011) 'Tabula picta' : aspetti giuridici del lavoro pittorico in Roma antica. Padova

Polichetti A (2001) Figure sociali, merci e scambi nell'edictum diocletiani et collegarum de pretiis rerum vanalium, Napoli

Pontrandolfo A (2002) Macedonia. In: Baldassarre et al 2002, pp 12-29

PPM I-XI = Baldassarre I (ed) (1990-2003) Pompei Pitture e Mosaici, IIX. Istituto della Enciclopedia Italiana, Roma

Rispoli C, Graziano SF, Di Benedetto C, De Bonis A, Guarino V, Esposito R, Morra V, Cappelletti P (2019) New insights of historical mortars beyond Pompei: the example of Villa del Pezzolo, Sorrento Peninsula. Minerals 9(10):575. https://doi.org/10.3390/min9100575

Robinson DM, Graham JW (1938) Excavation at Olynthus. Part VIII. The Hellenic House, Baltimore

Romizzi L (2006) Programmi decorativi di III e IV stile a Pompei. Un'analisi sociologica ed iconologica, Napoli

Rostovtzeff MI (2003) [1913] La peinture décorative antique en Russie méridionale, Paris

Rouveret A (1989) Histoire et imaginaire de la peinture ancienne (Ve siècle av. J.-C. - Ier siècle ap. J.-C.). Rome

Rouveret A (2002) Vitruve et les faux-semblants. In: A Pontrandolfo (ed) La pittura parietale in Macedonia e Magna Grecia: atti del Convegno internazionale di studi in ricordo di Mario Napoli (Salerno Paestum, 21-23 novembre 1996). Salerno, pp 105-124

Rouveret A (2002b) Roma: Casa dei Grifi. In: Baldassarre et al. 2002, 88

Salvadori M (2008) Amoenissimam parietum picturam. La fortuna del paesaggio nella pittura parietale romana, Eidola 5:23-46

Salvadori M (2012) Decorazioni ad affresco. In: Atria longa patescunt. Antenor Quaderni 23. Padova, pp 251-270

Salvadori M (2017) Horti Picti. Forma e significato del giardino dipinto nella pittura romana. Antenor Quaderni 36, Padova

Salvadori M, Didonè A (2018) La pittura parietale in Cisalpina: quadro di sintesi su una produzione di «confine». In: Dubois Y, Niffeler U (eds) (2018) Pictores per provincias, II. Status quaestionis, Actes du $13^{\mathrm{e}}$ colloque de l'Association Internationale pour la Peinture Murale Antique (AIPMA), (Lausanne, 12-16 septembre 2016). Antiqua 55. Basel, pp 583-589

Salvadori M, Scagliarini D, Coralini A, Didoné A, Helg R, Malgieri A, Salvo G (2015) TECT 1. Un progetto per la conoscenza della pittura parietale romana nell'Italia settentrionale. Antenor Quaderni 34. Padova

Salvo G (2018) Pinacothecae. Testimonianze di collezionismo di quadri nel mondo antico. Antenor Quaderni 43. Padova
Salvo G (2020) Introduzione alla Pittura Romana. Archeo Monografie 35

Sampaolo V (2009) La tecnica della pittura antica. In: Bragantini and Sampaolo 2009, pp 29-36

Sauron G (1998) La Grande fresque de la Villa des Mystères à Pompéi, Paris

Sauron G (2009) Il volto segreto di Roma. L'arte privata tra la Repubblica e l'Impero, Milano

Schiavi E (1957-1958) Ritrovamenti della tecnica pittorica dell'encausto. In: Atti del Settimo congresso internazionale di archeologia classica (Roma-Napoli 1958) 1 IX, 1957-1958

Schiavi E (1961) Il sale della terra, Verona

Settis S (2006) Il papiro di Artemidoro: un libro di bottega e la storia dell'arte antica. In: Gallazzi C, Settis S (eds) Le tre vite del papiro di Artemidoro. Voci e sguardi dall'Egitto greco Romano, Catalogo della mostra (Torino, Palazzo Bricherasio 8 febbraio-7 maggio 2006), Torino

Settis S (2008) La villa di Livia. Le pareti ingannevoli, Milano

Smith RRR (1994) Spear-won land at Boscoreale: on the royal painting of a Roman villa. JRA VII:100-128

Švarcová S, Hradil D, Hradilová J, Čermáková Z (2021) Pigments Copper-based greens and blues. Archaeological and Anthropological Sciences https://doi.org/10.1007/s12520-02101406-0

Torelli M, Marcattili F (2010) La decorazione parietale domestica romano-italica tra fase medio-repubblicana e cultura della luxuria. In: Meetings between Cultures in the Ancient Mediterranean. Proceedings of the 17th International Congress of Classical Archaeology (Rome 22-26 sept. 2008). Bollettino di Archeologia on line I 2010/ Volume speciale: 40-55

Torelli M, Menichetti M, Grassigli G (2011) Arte e archeologia del mondo romano, Milano

Tortorella S (2009) Dipingere il quotidiano: la pittura "popolare". In: La Rocca E, Ensoli S, Tortorella S, Papini M (eds) (2009), pp 115-129

Tybout A (1989) Aedificiorum figurae: Untersuchungen zu den Architekturdarstellungen des frühen zweiten Stils, Amsterdam

Varone A (1995) L'organizzazione del lavoro in una bottega di decoratori: evidenze dal recente scavo pompejano lungo via dell'Abbondanza. In: Moormann EM (ed) (1995a), pp 124-139

Varone A, Béarat H (1997) Pittori Romani al lavoro: materiali, strumenti, tecniche. Evidenze archeologiche e dati analitici di un recente scavo pompeiano lungo via dell'Abbondanza (Reg. IX. Ins. 12). In: Béarat H, Fuchs M, Maggetti M, Paunier D (eds), pp 199-214

Versluys MJ (2002) Aegyptiaca Romana: Nilotic Scenes and the Roman Views of Egypt, Leiden

Vitti P (2021) Mortars and masonry - structural lime and gypsum mortars in Antiquity and Middle Ages. Archaeological and Anthropological Sciences https://doi.org/10.1007/s12520-021-01408-y

Vitruvius (1934) On Architecture, Volume II: Books 6-10. Translated by Frank Granger. Loeb Classical Library 280. Cambridge, MA: Harvard University Press

Vlad Borrelli L (2015) La pittura murale nell'antichità. Storia, tecniche, conservazione. Roma

Von Blanckenhagen P H (1962) The paintings from Boscotrecase. In: RM suppl. 6. Heidelberg

Wallace-Hadrill A (1994) Houses and society in Pompeii and Herculaneum. Princeton

Zevi F (1998) Die Casa del Fauno in Pompeji und das Alexandermosaik. RM 105:21-65

Publisher's note Springer Nature remains neutral with regard to jurisdictional claims in published maps and institutional affiliations. 